\title{
Title: Estimates and Correlates of District-Level Maternal Mortality Ratio in India
}

First Author: Srinivas Goli, PhD (Corresponding Author)

Australia India Institute (AII) NGN Research Fellow

UWA Public Policy Institute

University of Western Australia (UWA)

35 Stirling Highway

Perth WA 6009

Australia

Email: srinivas.goli@uwa.edu.au

$\mathrm{T}+61864882914, \mathrm{M}+61$ 41`6271232

\&

Assistant Professor, Population Studies

Centre for the Study of Regional Development

Room No. 102, School of Social Sciences (SSS-III)

Jawaharlal Nehru University (JNU)

New Delhi-110067

Phone No: 01126738798

The University of Western Australia (M251),

35 Stirling Highway,

6009 Perth, Australia

Email: srinivas.goli@uwa.edu.au; sirispeaks2u@gmail.com

http://orcid.org/0000-0002-8481-484X

\section{Second Author: Parul Puri}

Department of Mathematical Demography and Statistics, International Institute for Population Sciences

Mumbai, Maharashtra, India

Email:parulpuri93@gmail.com; parul@iips.net

https://orcid.org/0000-0001-6272-837X

Third Author: Pradeep S. Salve, PhD

Assistant Professor,

Population Research Centre (PRC),

Dharwad, Karnataka - 580 004, India

Phone No: +91 9867954621

Email: pradeep_salve@ biari.brown.edu ,pradeep8889@gmail.com

ORCID: https://orcid.org/0000-0002-6879-1246

Fourth Author: Saseendran Pallikadavath, PhD

Professor in Demography and Global Health,

Portsmouth-Brawijaya Centre for the Global Health,

Population and Policy,

University of Portsmouth, United Kingdom

Phone No: +44 (0) 2392844442

Email: sasee.pallikadavath@port.ac.uk

https://orcid.org/0000-0002-2598-9949

NOTE: This preprint reports new research that has not been certified by peer review and should not be used to guide clinical practice. 
medRxiv preprint doi: https://doi.org/10.1101/2021.09.28.21264229; this version posted October 15, 2021. The copyright holder for this preprint (which was not certified by peer review) is the author/funder, who has granted medRxiv a license to display the preprint in All rights reserved. No reuse allowed without permission.

Fifth Author: K.S. James, PhD

Director \& Senior Professor

International Institute for Population Sciences (IIPS),

Govandi Station Road, Deonar,

Mumbai - 400088, India

Phone No: 022-42372888

Email: ksjames@iips.net; ksjames@gmail.com

https://orcid.org/0000-0002-5364-5326

\title{
Estimates and Correlates of District-Level Maternal Mortality Ratio in India
}

\begin{abstract}
Despite the progress achieved, approximately one-quarter of all maternal deaths worldwide occur in India. Till now, India monitors maternal mortality in 18 out of its 36 provinces using information from the periodic sample registration system (SRS). The country does not have reliable routine information on maternal deaths for smaller states and districts. And, this has been a major hurdle in local-level health policy and planning to prevent avoidable maternal deaths. For the first time, using triangulation of routine records of maternal deaths under Health Management Information System (HMIS), Census of India, and SRS, we provide Maternal Mortality Ratio (MMR) for all states and districts of India. Also, we examined sociodemographic and health care correlates of MMR using large-sample and robust statistical tools. The findings suggest that $70 \%$ of districts (448 out of 640 districts) in India have reported MMR above 70 deaths-a target set under Sustainable Development Goal-3. According to SRS, only Assam shows MMR more than 200, while our assessment based on HMIS suggests that about 6-states (and two union territory) and 128-districts have MMR above 200. Thus, the findings highlight the presence of spatial heterogeneity in MMR across districts in the country, with spatial clustering of high MMR in North-eastern, Eastern, and Central regions and low MMR in the Southern and Western regions. Even the better-off states such as Kerala, Tamil Nadu, Andhra Pradesh, Karnataka, and Gujarat have districts of mediumto-high MMR. In order of their importance, fertility levels, the sex ratio at birth, health infrastructure, years of schooling, post-natal care, maternal age and nutrition, and poor economic status have emerged as the significant correlates of MMR. In conclusion, we show that HMIS is a reliable, cost-effective, and routine source of information for monitoring maternal mortality ratio in India and its states and districts.
\end{abstract}


medRxiv preprint doi: https://doi.org/10.1101/2021.09.28.21264229; this version posted October 15,2021 . The copyright holder for this preprint (which was not certified by peer review) is the author/funder, who has granted medRxiv a license to display the preprint in

All rights reserved. No reuse allowed without permission.

\section{Key questions}

\section{What is already known?}

- Despite the progress achieved, approximately one-quarter of all maternal deaths worldwide occur in India.

- Maternal mortality prevalence is highly heterogeneous across the major provinces of India.

- So far country monitors maternal mortality in 18 out of 36 states using information from the periodic sample registration system (SRS).

- Clinical and socio-demographical reasons for maternal mortality have been studied using hospital-based studies and micro-level qualitative studies.

\section{What are the new findings?}

- For the first time, the study provides maternal mortality ratio (MMR) estimates for all states and districts of India.

- The findings suggest that $70 \%$ of districts (448 out of 640 districts) in India have reported MMR above 70 deaths per 1000 live births - a target set under Sustainable Development Goal-3.

- According to SRS, only Assam shows MMR of more than 200, while our estimates based on HMIS suggest that 6 states (and two union territory) and 128 districts demonstrate MMR above 200.

- The findings highlight the presence of spatial heterogeneity among districts in the country, with spatial clustering of high MMR in North-eastern, Eastern, and Central regions; and low MMR in the Southern and Western regions. We have also observed considerable within-state variations - across districts.

- Using a larger sample and robust statistical process, the study documents sociodemographic and health care correlates of MMR across the districts of India.

\section{What do the new findings imply?}

- Findings help in identifying 'hot spots' within the states and key socio-demographic and health care correlates of maternal mortality, thus assisting in micro-level maternal health care policy and planning.

- Availability of health infrastructure, access to affordable and quality maternal health care, especially in districts with high fertility, low education, and economically poor are key pathways to reduce maternal mortality in India.

- A significant association between sex ratio at birth and MMR suggest that, maternal deaths are also happening due to unsafe abortions, thus this needs policy attention.

- HMIS is a reliable, cost-effective, and routine source for monitoring progress in the reduction of avoidable maternal mortalitv in India and its states and districts. 
medRxiv preprint doi: https://doi.org/10.1101/2021.09.28.21264229; this version posted October 15, 2021. The copyright holder for this preprint (which was not certified by peer review) is the author/funder, who has granted medRxiv a license to display the preprint in

All rights reserved. No reuse allowed without permission.

\section{INTRODUCTION}

Maternal mortality refers to death from any complications during pregnancy and childbirth or within 42 days of termination of pregnancy, irrespective of the duration and site of the pregnancy, but not from accidental or incidental causes ${ }^{1}$. Maternal Mortality Ratio (MMR) is the number of deaths per 100,000 live births. The recent global MMR estimates suggest significant progress. In particular, from 2000 to 2017, we notice a 38\% decline in MMR - from 342 deaths to 211 deaths per 100,000 live births $^{2}$. However, this average annual rate of reduction $(2.2 \%)$ is less than the rate of decline needed $(2.7 \%)$ to achieve the Sustainable Development Goal (SDG-3.1) of 70 maternal deaths per 100,000 live births by $2030^{3}$. Though the improvement is remarkable in the context of a steep decline in the absolute number of maternal deaths from 451,000 in 2000 to 295,000 in 2017 deaths, it is still 800 women dying each day due to pregnancy complications and childbirth worldwide. Sub-Saharan Africa and South Asia contributed about $86 \%$ of maternal deaths in the world. In particular, South Asia accounts for $20 \%$ of maternal deaths, with 163 maternal deaths per 100,000 live births. Among South Asian countries, India is home to the highest number of maternal deaths ( 35000 maternal deaths) estimated globally in 2017. In percentage, the country accounts for $12 \%$ of global maternal deaths, next only to Nigeria (23\%) ${ }^{2}$.

According to the estimates of the Sample Registration System (SRS) of India, the MMR has significantly dropped from 400 per 100,000 live births in the early 1990s to 230 in 2008 and 130 in $2016^{45}$. Recent estimates of SRS have witnessed a steady decline in the MMR from 130 to 113 per 100,000 live births, with the highest rate in the state of Assam ( 215 per 100,000 live births) and lowest in the state of Kerala (43 per 100,000 live births) ${ }^{5}$. The findings of previous studies indicate that even though the overall MMR of India has drastically declined, the rate of decline in MMR is not uniform across the states 57891011 . Empowered Action Group (EAG) states including Bihar, Madhya Pradesh, Rajasthan, Uttar Pradesh, and Assam contributed approximately $75 \%$ of the total estimated maternal deaths in India and Uttar Pradesh alone has more than $30 \%$ of the maternal deaths ${ }^{59} 10$.

The Government of India launched National Health Mission (NHM) in 2015, subsuming the previous National Rural Health Mission (NRHM) and National Urban Health Mission (NUHM) to bring out the necessary structural changes in public health care and delivery system in India. The NHM design provides the Reproductive-Maternal-Neonatal-Child and Adolescent Health $(\mathrm{RMNCH}+\mathrm{A})$ services, strengthening the health system to achieve the important demographic and health goals. Schemes like Janani Suraksha Yojana (JSY) under NRHM have contributed significantly to the rise in antenatal care and institutional deliveries, thereby reducing $\mathrm{MMR}^{12} 1314$. Some of the states have already achieved or are about to achieve the SDG goal of reducing the MMR to 70 per 100,000 live births by $2030^{515}$. Nonetheless, seven out of eight EAG states, including Bihar, Madhya Pradesh, Chhattisgarh, Odisha, Rajasthan, Uttar Pradesh and Uttarakhand, still have a long way to go to achieve the target set under SDG- $3^{5}$.

Owing to data limitations, previous studies in India documented trends and patterns in MMR for only major states and 284 districts in nine empowered action group states, while the smaller states are completely excluded from the analyses ${ }^{513}{ }^{16}$. For a long time, the SRS has been the only reliable source of maternal mortality, which provides estimates for 18 major states ${ }^{5}$. Although the Annual Health Survey (AHS) provided MMR estimates for 284 districts in nine EAG states from 2010 to $2013^{4}$, the survey was repealed thereafter, assuming 
medRxiv preprint doi: https://doi.org/10.1101/2021.09.28.21264229; this version posted October 15,2021 . The copyright holder for this preprint (which was not certified by peer review) is the author/funder, who has granted medRxiv a license to display the preprint in All rights reserved. No reuse allowed without permission.

that NFHS would be redesigned to provide district-level health indicators for all Indian districts ${ }^{17}$. However, MMR estimates based on AHS never received as much prominence as SRS. Moreover, considering within-state heterogeneity observed in other maternal and child health care indicators ${ }^{18}$, we believe that there must be considerable within-state variation in MMR. However, to our knowledge, so far, there is not a single study in India that provides MMR estimates for the smaller states and all the districts of India.

On the other hand, earlier studies that investigated socio-economic, demographic, and health care correlates of maternal mortality using either macro-level analyses based on the sample of 15 to 19 states or with the help of micro-level qualitative studies have limitations ${ }^{8}$ 1318 . The socio-economic correlates identified based on the sample ranging from 15 to 18 states are less reliable, while micro-level local evidence is not nationally representative. Although a significant number of studies have documented clinical causes of maternal deaths ${ }^{7} 10192021$, the identification of socio-economic, demographic, and health care correlates immensely helps in designing policies and practices to avoid the death of women during pregnancy.

In the above context, this study makes two significant contributions: (1) for the first time, using Health Management Information System (HMIS) data, we provide MMR estimates for all 640 districts from 29 states and seven union territories of India. (2) Also, using the districtlevel information from National Family Health Survey (NFHS) alongside HMIS, we have assessed socio-economic, demographic and health care correlates of MMR based on a significantly larger sample than previous studies. Also, for the first time, we have included district-level health infrastructure index and maternal health care variables as predictors of MMR.

\section{METHODS}

\section{Data input and processing}

The study used data from multiple sources - HMIS (2017-18, 2018-19, 2019-20), the Sample Registration System (SRS, 2017-18), the Census of India (2011), and the National Family Health Survey (NFHS-4, 2015-16). The HMIS data source is the official data source of the Ministry of Health and Family Welfare (MoHFW), Government of India ${ }^{22}$. It provides the consolidated public and private health facility-based service statistics data for India on the reproductive, maternal, neonatal, child, and adult health indicators. We have accessed the unit level data through the open access link (https://hmis.nhp.gov.in/\#!/standardReports) available in the public domain from the HMIS website.

An independent evaluation of completeness of HMIS records of maternal and child health indicators in 2016 suggests an average of $88.5 \%$ completeness, while it is as high as $94.6 \%$ for maternal health care indicators ${ }^{23}$. Moreover, HMIS has been continuously improving its information recording system over the years. Thus, we would expect much better quality information for the years 2018 to 2020 than what was observed in 2016.

The SRS has been a gold standard source for fertility and mortality data for more than five decades and the largest demographic and health survey in the country, which gives reliable estimates at the national and state level separately by urban and rural areas. The dual registration system, huge sample size and verbal autopsy instruments make the estimates of SRS more reliable and representative at the national and state level (for details, see Office of the Registrar General of India, 2020) ${ }^{5}$. The NFHS is the largest sample survey that provides information on population, health, and nutrition for states and districts of India (for details 
medRxiv preprint doi: https://doi.org/10.1101/2021.09.28.21264229; this version posted October 15, 2021. The copyright holder for this preprint (which was not certified by peer review) is the author/funder, who has granted medRxiv a license to display the preprint in All rights reserved. No reuse allowed without permission.

see IIPS and ICF Macro, 2017) ${ }^{18}$. The population of women in the age group 15-49 years is drawn from the Census of India $2011^{24}$.

For the present study, we have analysed a total of $61,982,623$ live births and 61,169 maternal deaths recorded in HMIS during 2017-19. HMIS enumerated numbers are considerably higher than the SRS sample of 429,173 live births and 525 maternal deaths at the all-India level during 2015-17. Further, the estimated annual number of births in India based on the birth rate from SRS is about 25 million in recent years that will amount to about 75 million in three years from 2017 to $2019^{5}$. This suggests that HMIS covers nearly $77 \%$ of all live births in India and such a high number can produce fairly reliable estimates despite potential coverage errors. This study is reported as per the Strengthening the Reporting of Observational Studies in Epidemiology (STROBE) guidelines (Supplementary Table 1). However, this study did not have a prespecified analysis plan.

\section{Patient and Public Involvement}

It was not appropriate or possible to involve patients or the public in the design, or conduct, or reporting, or dissemination plans of our research.

\section{Variables}

Our outcome variable is the MMR estimated using live births and maternal deaths recorded through HMIS during 2017-20. Based on variables related to maternal deaths in the previous literature 6781013192025 and also considering data availability, we have included some key maternal health care, demographic and socioeconomic predictors to explain MMR variation across the districts of India. The predictor variables include health infrastructure index (HII) antenatal care, post-natal care, institutional delivery, mean age at first birth, contraception use in women, the mean number of children ever born, percentage of underweight, and anaemic women, years of schooling, household size, percentage of women in poor wealth status, and the sex ratio at birth. Detailed definitions and descriptions of the variables are mentioned in Table 1 and Table 2, respectively.

\section{Estimation of Maternal Mortality Ratio (MMR)}

We used triangulation of data from the HMIS, SRS, and Census of India (2011) to derive the final MMR estimates. A calibration factor (Cf) was computed and used to account for the under-(over)-reporting of maternal deaths by states and districts of India. The calibration factor was initially estimated for states, as the ratio of MMR from SRS and HMIS as shown in equation (1). For the states where MMR estimates were missing, we used the estimates of Infant Mortality Rates (IMR) as a proxy to MMR estimates to compute the calibration factor. In this case, the calibration factor was the ratio of IMR from SRS and HMIS, as shown in equation (2). The mathematical expressions for the aforementioned computations are as follows:

$$
\mathrm{Cf}=\frac{\text { SRS_MMR }^{\text {State_Estimate }}}{\text { HMIS_MMR }_{\text {State_Estimate }}}
$$

And, for the states where MMR is missing in SRS, we utilized the value of IMR as a proxy. In this case, the expression for computation of $\mathrm{Cf}$ can be written as follows:

$$
\mathrm{Cf}=\frac{\text { SRS_IMR }_{\text {State_Estimate }}}{\text { HMIS_IMR }^{\text {State_Estimate }}}
$$


medRxiv preprint doi: https://doi.org/10.1101/2021.09.28.21264229; this version posted October 15, 2021. The copyright holder for this preprint (which was not certified by peer review) is the author/funder, who has granted medRxiv a license to display the preprint in All rights reserved. No reuse allowed without permission.

Then, we have adjusted the district estimates of each state using the calibration factor (Cf) derived for that particular state using the aforementioned procedure in equations 1 and 2 . The adjusted MMR for each district was derived as below:

$$
\text { District } \mathrm{MMR}^{\text {Adjusted }}=\text { District } \mathrm{MMR}^{\text {Unadjusted }} * \mathrm{Cf}
$$

Finally, we have derived the adjusted state estimates using adjusted district MMRs and district population weights. Population weight for each district is derived using the information on women 15-49 years of age from Census of India, 2011. This procedure will adjust for district-level unequal size in error margins proportionately weighted by population size while deriving the state-level adjusted MMRs using HMIS data. The estimated MMR for each state is as follows:

$$
\text { State } \mathrm{MMR}^{\text {Adjusted }}=\frac{\sum_{\mathrm{i}=1}^{\mathrm{n}} \text { District MMR }^{\text {Adjusted }_{* \mathrm{pw}}}}{\mathrm{n}}
$$

Where pw is population weight defined as:

$$
\mathrm{pw}=\frac{\text { Total female population of the district in age } 15-49 \text { years }}{\text { Total female population of the State in age } 15-49 \text { years }}
$$

\section{Geographical distribution and spatial clustering}

We have carried out statistical analyses in three stages: First, used GIS mapping to show the geographical distribution of MMR across the states and districts of India. In the second stage, to assess the extent of geographical clustering, univariate local Moran's I and Local indicator of Spatial Association (LISA) cluster and significance maps were employed. Spatial proximity was quantified using the Queen contiguity matrix, which includes neighbours sharing geographical boundaries of non-zero length ${ }^{26}$. Moran's I statistics range between -1 and +1 , where a positive, negative and zero value is indicative of positive, negative, and no spatial autocorrelation, respectively ${ }^{27}$ 28. Cluster map depicts the locations (districts) with a significant local Moran's I statistic classified by spatial auto-correlation type; the color red symbolises the hot spots (districts with high MMR levels, with similar neighbours), green symbolises the cold spots (districts with low MMR levels, with similar neighbours), and the light blue and light red color symbolizes the spatial outliers (districts with high MMR levels, but with low- MMR level neighbours and vice-versa).

\section{Ordinary least square regression model: Macro-level correlates}

In the last stage, we have carried out an Ordinary least square (OLS) log-linear regression model to understand the maternal health care, demographic and socioeconomic correlates of MMR. We have modelled six OLS regressions to avoid the collinearity between the explanatory variables. Except for model 6 , we have avoided highly collinear variables $(r>0.60)$ in the same model based on the correlation matrix of the study explanatory variables.

The mathematical expression of the model is given below:

$$
\mathrm{Y}_{(\text {Log_MMR) }}=\mathrm{a}+\mathrm{b}_{1} X_{1 \text { (Log_HII) }}+\mathrm{b}_{2} X_{2 \text { (Log_No.of ANCs) }}+\mathrm{b}_{k} X_{k \ldots}+\varepsilon_{i}
$$

Where $Y$ is the outcome variable (i.e. MMR), which is influenced by a set of predictor variables $\mathrm{X}_{1}, \mathrm{X}_{2}, \mathrm{X}_{3}-------\mathrm{X}_{\mathrm{K}}$ (e.g., HII, antenatal care, postnatal care, institutional delivery, mean age at first birth) in the manner specified with parameters $\beta_{1}, \beta_{2}$...... $\beta_{K}$. 
medRxiv preprint doi: https://doi.org/10.1101/2021.09.28.21264229; this version posted October 15, 2021. The copyright holder for this preprint (which was not certified by peer review) is the author/funder, who has granted medRxiv a license to display the preprint in All rights reserved. No reuse allowed without permission.

Statistical analyses were performed using STATA 16 statistical software (Stata Corporation, College Station, TX, USA).

\section{RESULTS}

\section{Geographical variation and spatial clustering of maternal mortality}

Figure 1 depicts the spatial pattern of MMR across 29 states and 7 union territories in India. Findings underline considerable geographical heterogeneity in MMR across Indian states. MMR was categorised into four groups, less than 70,70-139, 140-209, greater than or equal to 210 deaths per 100000 live births. The first cut-off was taken at 70 which is a primary target under SDG-3 for MMR; while the second cut-off at 140 is a second target under SDGs. Further, the same interval has been taken to create two more categories ${ }^{15}$. Such categorisation allows classifying Indian states and districts as those achieved, near to achieve, or far from the achievable SDG target 3.1.

Among the states, the highest MMR is found in Arunachal Pradesh (284) and the lowest in Maharashtra (40). The findings illustrate that five states, including Arunachal Pradesh (284), Manipur (282), Andaman and Nicobar Island (275), Meghalaya (266), and Sikkim (228), have MMR greater than or equal to 210. Nine States and two Union Territories have MMR in the range of 140-209. These states are Nagaland (143), Punjab (143), Chhattisgarh (144), Jammu and Kashmir (151), Delhi (162), Rajasthan (162), Bihar (164), Madhya Pradesh (179), Lakshadweep (208), Uttar Pradesh (208), and Assam (209).

Eleven states have MMR in the range of 70-139: Gujarat (76), Jharkhand (78), Karnataka (85), Haryana (90), Goa (91), West Bengal (100), Uttarakhand (107), Tripura (119), Himachal Pradesh (127), Mizoram (131), and Odisha (138). Furthermore, the estimates indicate that nine out of 36 provinces have MMR less than 70: Chandigarh (15), Maharashtra (40), Puducherry (41), Kerala (44), Daman and Diu (48), Telangana (53), Tamil Nadu (56), Dadra and Nagar Haveli (61) and Andhra Pradesh (64) (Supplementary Table 2).

[Figure 1 Geographical pattern of maternal mortality ratio by states/union territories in India, HMIS]

Figure 2 depicts the geographical pattern of MMR in 640 districts of India. Among the districts, the highest MMR is found in Tirap district in Arunachal Pradesh (1671), while thirteen districts reported lowest MMR levels, these included seven districts from Arunachal Pradesh (0), two districts from Himachal Pradesh (0) and one district from Jammu \& Kashmir (0), Maharashtra (0), Puducherry (0), and Uttrakhand (0), each. The results indicate that 192 districts have MMR less than 70 and 210 districts fall in the range of 70-139. However, about 124 districts have MMR in the range 140-209, and 114 districts fall in the category of greater than or equal to 210. In particular, among the districts with MMR greater than or equal to 210, 46 districts belonged to the Central Region, and 33 districts are located in the Northeastern region; while 18 districts belonged to the Northern region and 16 to the Eastern region.

A majority of the districts in southern India and Maharashtra have an MMR of less than 70. Around 70 districts from Southern (68 district) India have MMR less than 70, followed by Western (46 districts), Eastern (30 districts), and Northern (30 districts) regions. While Northeastern (12 district) and Central (6 districts) regions have the least number of districts that achieved the primary SDG target of MMR (Supplementary Table 3). 
medRxiv preprint doi: https://doi.org/10.1101/2021.09.28.21264229; this version posted October 15,2021 . The copyright holder for this preprint (which was not certified by peer review) is the author/funder, who has granted medRxiv a license to display the preprint in All rights reserved. No reuse allowed without permission.

However, Figure 2 also demonstrates the presence of huge within-state inequalities. For instance, the state of Karnataka as a whole, falls in the category of 70-139, but several of its districts have an MMR above 140. Similarly, some districts in Tamil Nadu, Kerala, Andhra Pradesh, and Telangana also have MMR above 140, despite all four states falling in the category of MMR below 70 at state level. A similar kind of district-level heterogeneity is observed in other states as well.

[Figure 2 Geographical pattern of maternal mortality ratio by 640 districts in India, HMIS]

Supporting these findings, the results from univariate LISA (Figure 3) also suggest the presence of spatial heterogeneity in MMR with statistically significant spatial autocorrelation (Moran's I $=0.229, p$-value $=0.001$ ) across districts in the country. Geographical clustering of high MMR was observed in the North-eastern and parts of the Central region. Southern and Western regions in the country reported a noticeable geographical clustering of low MMR.

[Figure 3. Univariate Moran's I for Maternal Mortality Ration in India]

Furthermore, bivariate LISA assessed the spatial association between the selected background variables and MMR for 640 districts in the country. The findings from the bivariate spatial analysis are presented in Supplemental Figure 1. Bivariate analysis suggests that regions with low age at first birth, low contraception use, high mean number of children ever born, higher percentage of underweight and anaemic women are more likely to report higher MMR. Also, the MMR is found to be higher for the districts with a lower percentage of four or more ANC, lower percentage of post-natal care, lower percentage of institutional deliveries, and lower health infrastructure. Lower percentage of ten or more years of schooling, higher mean household size, low percentage urban population, and higher percentage poor economic status are more likely to report higher MMR among districts in India. However, there are several exceptional cases found where regions with higher age at first birth and lower prevalence of anaemic women also found with higher MMR, thus indicating spatial heterogeneity in the relationship between MMR and socio-economic characteristics. It also suggests that MMR is influenced by a multitude of factors, thus investigation of the net effect of socioeconomic correlates controlling for confounders is important.

\section{Factors associated with maternal mortality: a macro-level analysis}

Table 3 presents the net effect of socio-economic, demographic, and health care correlates of maternal mortality ratio based on the OLS regression model. In model 1 , before controlling for other correlates, ANCs $(\beta=-0.273, p<0.01)$ is negatively associated with MMR. However, in models 2, 5, and 6, when we controlled for all other correlates, 4 or more ANC visits do not show the desired relationship with MMR. Similarly, when we run the regression model considering only health infrastructure and maternal health care variables, health infrastructure $(\beta=-0.551, p<0.01)$ and PNCs within 48 hours of delivery $(\beta=-0.279, p<0.1)$ are negatively associated and statistically significant. Surprisingly, institutional delivery is positively associated and statistically not significant across all the models.

Using only demographic variables, the results in model-3 suggest that age at first birth ( $\beta=$ $7.905, p<0.1)$, ever use of contraception $(\beta=0.219, p<0.05)$ and children ever born $(\beta=1.822$, $p<0.01)$ are positively associated, while BMI $(\beta=-0.437, p<0.05)$ is negatively associated with 
medRxiv preprint doi: https://doi.org/10.1101/2021.09.28.21264229; this version posted October 15,2021 . The copyright holder for this preprint (which was not certified by peer review) is the author/funder, who has granted medRxiv a license to display the preprint in All rights reserved. No reuse allowed without permission.

MMR. Model 4 which uses only socio-economic variables reveals that the sex ratio at birth $(\beta=-1.218, p<0.01)$ is negatively associated, while the poor economic status of the households ( $\beta=0.215, p<0.01$ ) is positively linked to MMR. Share of SC/ST population is positively associated $(\beta=0.188, p<0.05)$ with MMR in Model 5 . Model 6 that controls for all variables suggests that health infrastructure $(\beta=-0.535, p<0.01)$, PNCs within 48 hours of delivery $(\beta=-$ $0.370, p<0.05), \mathrm{BMI}(\beta=-0.357, p<0.01)$ and year of schooling $(\beta=-0.437, p<0.01)$ are negatively associated, while age at first birth $(\beta=7.431, p<0.05)$ and children ever born $(\beta=$ $1.589, p<0.01)$ are positively and significantly correlated with MMR. The institutional deliveries continue to show statistically insignificant negative relationships.

\section{Robustness checks: Data reliability assessment}

The first robustness check parameter used in this study is estimation of completeness of birth registration in HMIS. The estimated annual number of births in India is about 81 million in three years from 2017 to 2019; while reported cumulative live births during 2017-19 under HMIS is 62 million - this suggest that HMIS has coverage of $77 \%$ of all estimated live births in the country. Among major states, with 95\%, Telangana and Kerala show the highest completeness of birth registration; while the corresponding figure is lowest in the state of Uttar Pradesh (62\%). However, 26 out 37 states and union territories have completeness of birth registration equal to or above the national average. Twenty out of 37 states and 17 of 37 states show above $80 \%$ and $85 \%$ of completeness of birth registration which indicates that HMIS information is highly reliable for deriving basic demographic estimates (Figure 4). Although the missing deaths or deaths that physicians were unable to code cannot be ignored but given their low proportion, conservatively it is safe to assume that they did not affect the general regional pattern of MMR shown in this study.

[Figure 4 Percentage of reported live births out of estimated live births by states in HMIS, 2017-19]

The second parameter used to make a reliability assessment of MMR estimates based on HMIS, is the comparison of MMR estimates from HMIS to corresponding estimates from SRS for the major states. At all India level, SRS shows 130 in 2014-16 and 113 in 2016-18, while HMIS reports 122 in 2017-19 (Supplementary Table 2). In Figure 5, we plot MMR estimates from SRS and HMIS. The MMR estimates from HMIS are close to SRS in socio-demographically better-off states (Andhra Pradesh, Gujarat, Karnataka, Tamil Nadu, and Kerala, Maharashtra, etc.), while the gap is slightly higher in socio-demographically weaker states (Assam, Bihar, Chhattisgarh, Uttar Pradesh, Madhya Pradesh, and Odisha). Despite a slight gap in MMR estimates from HMIS and SRS in a few states, the pattern remains more or less the same in the estimates from both sources: the MMR is higher in socio-demographically weaker states compared to their counterparts in socio-economically advanced states. The similar evidence can also be observed in case of comparison of IMR from SRS and MMR from HMIS. We found a high positive correlation between IMR from SRS and MMR from HMIS with a correlation coefficient of 0.78 (Figure 6).

[Figure 5 Correspondence between MMR estimates from SRS and HMIS]

[Figure 6 Correlation between IMR estimates from SRS and MMR estimates from HMIS] 
medRxiv preprint doi: https://doi.org/10.1101/2021.09.28.21264229; this version posted October 15, 2021. The copyright holder for this preprint (which was not certified by peer review) is the author/funder, who has granted medRxiv a license to display the preprint in All rights reserved. No reuse allowed without permission.

Thirdly, comparison MMR estimates from other sources with our estimates suggest that both SRS and HMIS based MMR is much lower than the Global Burden of Disease (GBD) study estimate of 247.6 for 2015, but closer to estimates (145 in 2017) by WHO, UNICEF, UNFPA, World Bank Group and the United Nations Population Division ${ }^{2} 5$. Overall, our MMR estimates using HMIS more or less align with SRS estimates and the estimates from WHO, UNICEF, UNFPA, World Bank Group, and the United Nations Population Division ${ }^{2}$.

Fourth, we further compared a few other basic demographic estimates from HMIS (201719) with SRS (2018). For instance, IMR from HMIS (2017-19) is 26.2 against 32 from SRS (2018). Similarly, the Sex Ratio at Birth from HMIS (2017-19) is 108 against 111 from SRS (2018). While Crude Birth rate in HMIS is 24 , it is 20.2 in SRS. HMIS based IMR, SRB, and CBR estimates are also close to corresponding year estimates from the report of the technical group on population projections ${ }^{31}$ (Supplementary Table 4).

Fifth, the macro-level regression estimates showing expected direction of association between health infrastructure, maternal health care and socio-demographic indicators and MMR also strengthen our belief that the estimates are in line with the status of districts sociodemographic and health status. If there was a health facility-led bias in MMR registration, we would not have seen the expected direction of the relationship between these variables. Overall assessment of the quality of data reported in HMIS vis-à-vis gold standard SRS estimates suggests that HMIS fares well with slight discrepancies with reference to SRS. However, in the absence of other reliable data sources at the micro-level (district-level) in India, HMIS fills the gap with decent quality information that can help policy and planning at district level in the country.

\section{DISCUSSION}

Considering the global SDG targets, all countries are expected to have MMR below 70 per 100,000 live births, and no country with MMR above 140 per 100,000 live births by $2030^{3}$. In view of this, 71 percent of the total districts (456 out of 640 districts) in India have reported MMR above 140. According to SRS (2016-18), only Assam (215) has MMR of more than 200, while our district-level assessment based on HMIS suggests that about 130 districts have reported above 200 maternal deaths per 100,000 live births. Thus, our findings from mapping and spatial analyses highlight the presence of a greater spatial heterogeneity across districts in the country, with spatial clustering (hot-spots) of high MMR in the North-eastern and Central regions, and low MMR in the Southern and Western regions. However, we have also observed considerable within-state variations in states across their districts. Even the betteroff states such as Kerala, Tamil Nadu, Andhra Pradesh, Karnataka, and Gujarat have pockets of medium to high MMR that needs policy attention. Owing to data availability, so far, only Assam from the North-eastern region was in the lime-light for higher maternal deaths, but with this study, it has been learned that the entire region is facing a similar problem and needs policy attention.

Our assessment of socio-economic correlates of MMR suggests that improvement in antenatal care, postnatal care within 48 hours of delivery, BMI, years of schooling, and reduction of higher-order births, births in higher ages, and poor economic status will help in reducing $M M R$ in the districts of India. The districts with better health infrastructure have significantly less MMR, while those with a high SC/ST population show higher MMR levels. However, the most surprising factor is the lack of significant negative association of 
medRxiv preprint doi: https://doi.org/10.1101/2021.09.28.21264229; this version posted October 15, 2021. The copyright holder for this preprint (which was not certified by peer review) is the author/funder, who has granted medRxiv a license to display the preprint in

All rights reserved. No reuse allowed without permission.

institutional deliveries with MMR. Looking at this finding in conjunction with previous studies, which showed an unexpected relationship with both infant mortality and maternal mortality, suggests that it may be because a considerable number of women rush to institutional deliveries when complications arise; most often a majority of them have not obtained full and quality antenatal care ${ }^{11} 13$. Thus, the risky deliveries contribute to the greater number of deaths at the institutions compared to home deliveries ${ }^{12} 13{ }^{30}$. In particular, Randive and colleagues found that a gap exists between access to just institutional deliveries and access to emergency obstetric care, perhaps demonstrating that women delivering in institutions are not automatically receiving sufficient care ${ }^{16}$. Another startling finding is the positive relationship between contraceptive use and MMR. However, such a relationship is possible in the context of low quality of care in family planning which leads to greater maternal morbidity and increases the risk of obstetric complication and mortality ${ }^{18}$.

From a policy perspective, the findings of the study advance two key messages: first, despite decent progress in reducing maternal mortality, several districts in India need to initiate immediate action to meet the ambitious SDG-3 target of MMR, and ultimately eliminate preventable maternal mortality. Although the district-specific rates of reduction that are needed to achieve SDG targets are ambitious for most high MMR districts, the states that made a concerted effort to reduce maternal mortality, especially post-2005 provide pathways on how to accomplish the acceleration necessary to substantially reduce preventable maternal deaths. In particular, post-2005 MMR reduction in Maharashtra, Telangana, and Andhra Pradesh are very impressive ${ }^{513}$.

Secondly, the study highlights that maternal health care, especially postnatal care, and maternal nutrition are key for reducing maternal mortality. Considering that children ever born, years of schooling and poor household economic status also emerged as critical factors, avoiding higher-order births, ensuring dissemination of right maternal health knowledge and affordable essential services helps in accelerating the process of reduction in MMR. Despite JSY being in place, out of pocket expenditure on maternal health care in several states of India is way higher than JSY incentives ${ }^{32}$; which might be impacting on accessing quality antenatal and institutional delivery care and as a result, this is impacting on reducing maternal mortality. Therefore, ongoing Pradhan Mantri Matriva Vandhana Yojana (PMMVY) must consider the raising of JSY incentives to ensure affordable and quality maternal health care to all. Moreover, a significant association between sex ratio at birth and MMR suggests that, maternal deaths are also happening due to unsafe abortions, and thus needs policy attention. A highly developed state like Punjab falling in the moderate to high category of MMR also raises the question that unsafe sex-selective abortions may be contributing to maternal deaths.

Third, although the reliability of routinely recorded mortality data by health system employees has been continuously questioned ${ }^{33}$, if it is handled well, systems like HMIS would be a permanent solution to the long-standing problem of the absence of micro-level demographic and health information in India. Despite some caveats associated with HMIS data on maternal deaths, in the absence of any other reliable data sources at micro-level (district-level) in India, it fills the gap with decent quality information that can help policy and planning at district level in the country. In general, vital registration systems such as HMIS lack political priority in several states thus leading to poor management, supervision, and underfunding. While an efficient system of death reporting may be more complex and entail institutional arrangements across many governmental departments, they can be made to 
medRxiv preprint doi: https://doi.org/10.1101/2021.09.28.21264229; this version posted October 15, 2021. The copyright holder for this preprint (which was not certified by peer review) is the author/funder, who has granted medRxiv a license to display the preprint in

All rights reserved. No reuse allowed without permission.

work subject to strong regional momentum and leadership. Given the encouraging results already achieved with minimal support for HMIS, an integrated review system and supervision should probably produce better results. Therefore, our study will rejuvenate the plan of increasing efforts to revive the vital registration system at a national level with an inspiration of reasonably good quality registration evident in case of maternal deaths under HMIS.

\section{Acknowledgments}

We thank P.M. Kulkarni (Rtd Professor, Center for the Studies in Regional Development, Jawaharlal Nehru University) for numerous discussions about HMIS data and methodology of MMR estimation using HMIS; and also, for reviewing the first draft of the paper. We also thank Prof. Christophe Guilmoto (a senior fellow in Demography at the French Institut de Recherche pour le Développement (IRD)) and Prof. Arvind Pandey (Former Director, National Institute of Medical Statistics, New Delhi) for useful discussion about the demographic estimates using the vital registration system data.

Funding None declared

Competing interests None declared

Patient consent for publication Not required.

Provenance and peer review Not commissioned; externally peer-reviewed.

\section{Twitter Srinivas Goli @ SrinivasGoli1}

Contributors Srinivas Goli contributed to the study conceptualization. Srinivas Goli designed the study. Srinivas Goli and Pradeep Salve performed the literature search. K.S. James and Pradeep Salve undertook the data collection. Parul Puri and Srinivas Goli performed statistical analyses of all data in this study. Srinivas Goli, Parul Puri and Pradeep Salve drafted the manuscript. Saseendran Pallikadavath and K.S. James reviewed and finalized the draft. All authors analyzed and interpreted the results and provided comments on and critical revision of the manuscript. Saseendran Pallikadavath and K. S. James are the guarantors.

Data availability statement All data relevant to and included in the study are available in the public domain at the following links:

HMIS: https://hmis.nhp.gov.in/\#!/standardReports

NFHS-4, 2015-16: https://dhsprogram.com/data/available-datasets.cfm

ORCID iDs

Srinivas Goli https://orcid.org/0000-0002-8481-484X

Parul Puri https://orcid.org/0000-0001-6272-837X

Saseendran Pallikadavath https://orcid.org/0000-0002-2598-9949

Pradeep Salve https://orcid.org/0000-0002-6879-1246

K. S. James https://orcid.org/0000-0002-5364-5326

\section{Supplementary material}


medRxiv preprint doi: https://doi.org/10.1101/2021.09.28.21264229; this version posted October 15, 2021. The copyright holder for this preprint (which was not certified by peer review) is the author/funder, who has granted medRxiv a license to display the preprint in All rights reserved. No reuse allowed without permission.

Supplementary Table 1. STROBE Checklist. STROBE, strengthening the reporting of observational studies or cross-sectional studies in epidemiology. (DOC)

Supplementary Table 2 State-wise estimates of MMR from SRS and HMIS. (DOC)

Supplementary Table 3 District-wise estimates of MMR from HMIS. (DOC)

Supplementary Figure 1 Bivariate LISA (Cluster and Significance) maps depicting spatial clustering and spatial outliers of maternal mortality ratio by selected background characteristics in India. (DOC)

Supplementary Table 4 Comparison of Infant Mortality Rate, Sex Ratio at Birth and Crude Birth Rate from SRS and HMIS. (DOC)

\section{REFERENCE}

1 WHO. Mortality and burden of disease. World Heal. Organ. 2021.

2 World Health Organization (WHO). Maternal mortality : level and trends 2000 to 2017 Estimates by WHO, UNICEF, UNFPA, World Bank Group and the United Nations Population Division.

2019;:12.https://www.who.int/reproductivehealth/publications/maternal-mortality2000-2017/en/

3 Transforming our World: The 2030 agenda for Sustainable Development. United Nations Dev. Progr. 2015.https://sdgs.un.org/2030agenda

4 Ministry of Health and Family Welfare G of I. Special Bulletin on Maternal Mortality in India 2014-16. SRS Bull 2018;:1-

3.http://www.censusindia.gov.in/vital_statistics/SRS_Bulletins/MMR Bulletin-201416.pdf

5 Office of the Registrar General I. Special Bulletin on Maternal Mortality in India 201618. Sample Regist Syst 2020;:1-4.

6 Barros AJ, Ronsmans C, Axelson $\mathrm{H}$, et al. Equity in maternal, newborn, and child health interventions in Countdown to 2015: A retrospective review of survey data from 54 countries. Lancet 2012;379:1225-33. doi:10.1016/S0140-6736(12)60113-5

7 Montgomery AL, Ram U, Kumar R, et al. Maternal mortality in India: Causes and healthcare service use based on a nationally representative survey. PLoS One 2014;9. doi:10.1371/journal.pone.0083331

8 Jat TR, Deo PR, Goicolea I, et al. Socio-cultural and service delivery dimensions of maternal mortality in rural central India: A qualitative exploration using a human rights lens. Glob Health Action 2015;8:1-15. doi:10.3402/gha.v8.24976

9 Ministry of Health and Family Welfare; Government of India. Guidelines for Maternal Death Surveillance \& Response. 2017.

http://www.nhm.gov.in/images/pdf/programmes/maternalhealth/guidelines/Guideline_for_MDSR.pdf 
medRxiv preprint doi: https://doi.org/10.1101/2021.09.28.21264229; this version posted October 15, 2021. The copyright holder for this preprint (which was not certified by peer review) is the author/funder, who has granted medRxiv a license to display the preprint in All rights reserved. No reuse allowed without permission.

10 Horwood G, Opondo C, Choudhury SS, et al. Risk factors for maternal mortality among 1.9 million women in nine empowered action group states in India: secondary analysis of Annual Health Survey data. BMJ Open 2020;10:e038910. doi:10.1136/bmjopen-2020-038910

11 Salve PS, Naiker SK, Golandaj JA, et al. Situational analysis of maternal death review in India: Evidence from health management information system. Child Youth Serv Rev 2020;119:105723. doi:https://doi.org/10.1016/j.childyouth.2020.105723

12 Lim SS, Dandona L, Hoisington JA, et al. India's Janani Suraksha Yojana, a conditional cash transfer programme to increase births in health facilities: an impact evaluation. Lancet 2010;375:2009-23. doi:10.1016/S0140-6736(10)60744-1

13 Goli S, Jaleel ACP. What is the cause of the decline in maternal mortality in india? evidence from time series and cross-sectional analyses. J Biosoc Sci 2014;46:351-65. doi:10.1017/S0021932013000564

14 Randive BB, Chaturvedi SD, Diwan V, et al. Effective coverage of institutional deliveries under the Janani Suraksha Yojana programme in high maternal mortality provinces of India: analysis of data from an annual health survey. Lancet 2013;381:S123. doi:10.1016/s0140-6736(13)61377-x

15 United Nations. The Sustainable Development Goals Report-2018. New York: 2018.

16 Randive B, Diwan V, De Costa A. India's Conditional Cash Transfer Programme (the JSY) to Promote Institutional Birth: Is There an Association between Institutional Birth Proportion and Maternal Mortality? PLoS One 2013;8.

doi:10.1371/journal.pone.0067452

17. Krishnan, V. Govt discontinued annual health survey of India, $25 \mathrm{Jul} 2013$. https://www.livemint.com/Politics/zjD4pm80nNrUgpvbpcBRKK/Govt-discontinuesannual-health-survey.html.

18 IIPS, Macro I. National Family Health Survey (NFHS-4). 2017. http://rchiips.org/NFHS/NFHS-4Reports/India.pdf

19 Bhatia JC. Levels and Causes of Maternal Mortality in Southern India. Stud Fam Plann 1993;24:310-8.https://pubmed.ncbi.nlm.nih.gov/8296332/

20 Ganatra BR, Coyaji KJ, Rao VN. Too far, too little, too late: A community-based casecontrol study of maternal mortality in rural west Maharashtra, India. Bull World Health Organ 1998;76:591-8.https://pubmed.ncbi.nIm.nih.gov/10191555/

21 Bhattacharyya SK, Majhi AK, Seal SL, et al. Maternal mortality in India: A 20-year study from a large referral medical college hospital, West Bengal. J Obstet Gynaecol Res 2008;34:499-503. doi:10.1111/j.1447-0756.2008.00721.x

22 Ministry of Health \& Family Welfare (MoHFW), 2020, Health Management Information System (HMIS), 2017-2019, available online at http://nrhm-mis.nic.in.

23 Sharma A, Rana SK, Prinja S, et al. Quality of health management information system for maternal \& child health care in Haryana state, India. PLoS One 2016;11:1-11. doi:10.1371/journal.pone.0148449 
medRxiv preprint doi: https://doi.org/10.1101/2021.09.28.21264229; this version posted October 15, 2021. The copyright holder for this preprint (which was not certified by peer review) is the author/funder, who has granted medRxiv a license to display the preprint in All rights reserved. No reuse allowed without permission.

24 New Delhi: Office of the Registrar General and Census Commission. Ministry of Home Affairs G of I. Census of India 2011. 2011.www.censusindia.gov.in/2011common/census_2001.html

25 Vora DP, Shelke PS. Effects of health education tool on select epidemiological factors associated with adult obese urban slum women. Indian J Public Health 2017;61:25460. doi:10.4103/ijph.IJPH_99_16

26 Puri P, Khan J, Shil A, et al. A cross-sectional study on selected child health outcomes in India : Quantifying the spatial variations and identification of the parental risk factors. Sci Rep 2020;:1-15. doi:10.1038/s41598-020-63210-5

27 Getis A, Ord JK. The Analysis of Spatial Association by Use of Distance Statistics. 1992;24. doi:10.1111/j.1538-4632.1992.tb00261.x

28 Anselin L. Local Indicators of Spatial Association (LISA). Geogr Anal 1995;27:93-115. doi:10.1111/j.1538-4632.1995.tb00338.x

29 Kassebaum NJ, Barber RM, Dandona L, et al. Global, regional, and national levels of maternal mortality, 1990-2015: a systematic analysis for the Global Burden of Disease Study 2015. Lancet 2016;388:1775-812. doi:10.1016/S0140-6736(16)31470-2

30 Goldie SJ, Sweet S, Carvalho N, et al. Alternative strategies to reduce maternal mortality in India: A cost-effectiveness analysis. PLoS Med 2010;7. doi:10.1371/journal.pmed.1000264.

31. National Commission on Population (2020). Report on Population Projections for India and States, 2011-36, National Health Mission, Government of INDIA, New Delhi.

32. NSSO. National Sample Surveys (2018): Social consumption (Health) 2017-18, MoSPI, Government of India, New Delhi.

33. Pandey A, Roy N, Bhawsar R, Mishra RM. Health information system in India: issues of data availability and quality. Demography India. 2010 Jan;39(1):111-28. 
medRxiv preprint doi: https://doi.org/10.1101/2021.09.28.21264229; this version posted October 15, 2021. The copyright holder for this preprint (which was not certified by peer review) is the author/funder, who has granted medRxiv a license to display the preprint in All rights reserved. No reuse allowed without permission.

\section{Figures}

Figure 1. The geographical pattern of maternal mortality ratio by states/union territories in India, HMIS.

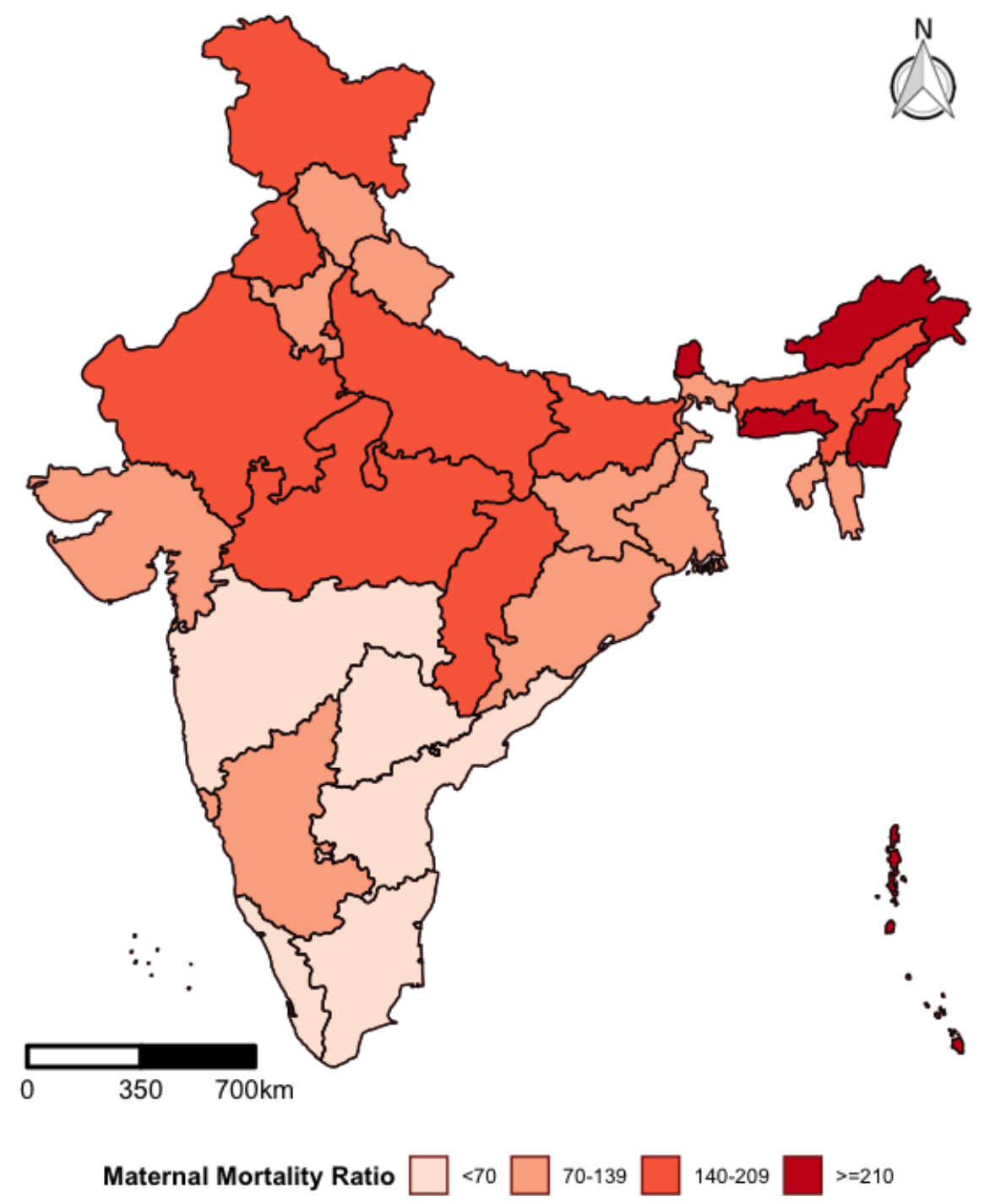


medRxiv preprint doi: https://doi.org/10.1101/2021.09.28.21264229; this version posted October 15, 2021. The copyright holder for this preprint (which was not certified by peer review) is the author/funder, who has granted medRxiv a license to display the preprint in All rights reserved. No reuse allowed without permission.

Figure 2. The geographical pattern of maternal mortality ratio by 640 districts in India, HMIS.

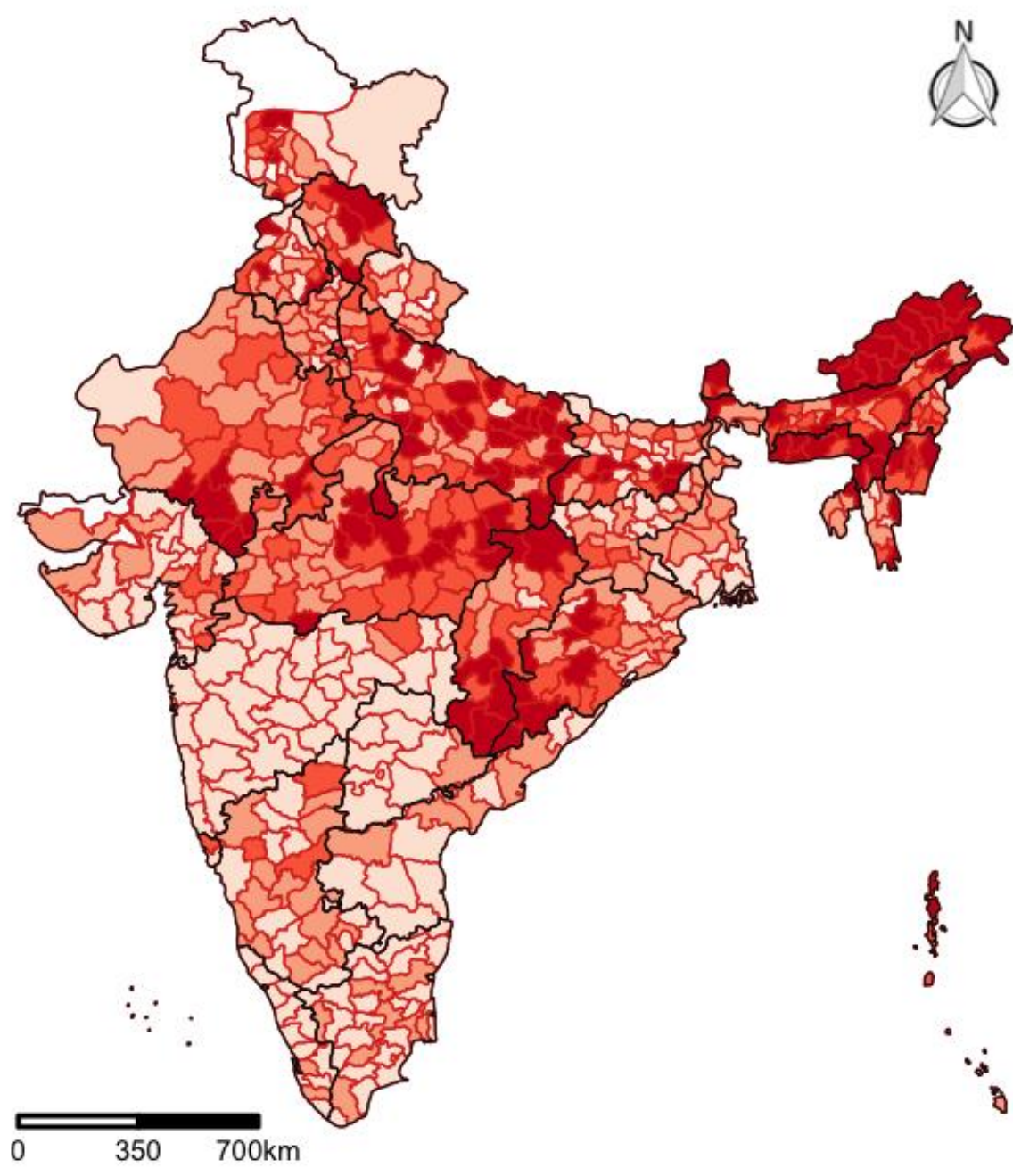

Maternal Mortality Ratio $\square<70 \square 70-139 \square 140-209 \square>=210 \square$ NA 
medRxiv preprint doi: https://doi.org/10.1101/2021.09.28.21264229; this version posted October 15, 2021. The copyright holder for this preprint (which was not certified by peer review) is the author/funder, who has granted medRxiv a license to display the preprint in All rights reserved. No reuse allowed without permission.

Figure 3. Univariate Moran's I for Maternal Mortality Ration in India.

A.

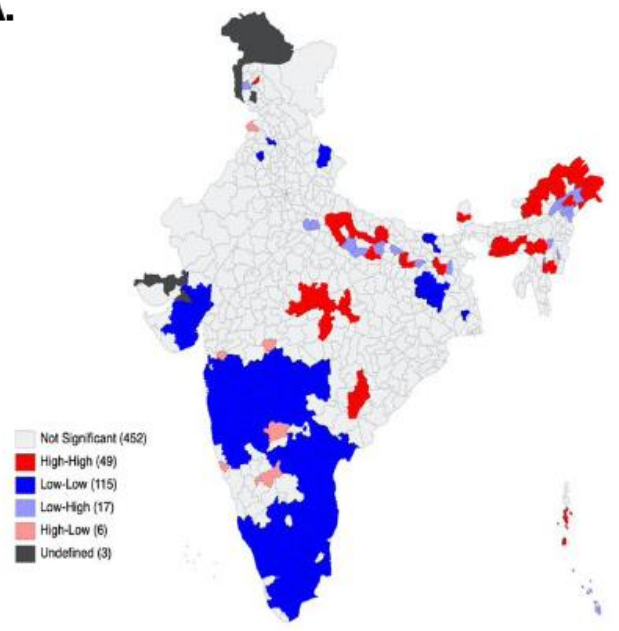

B.

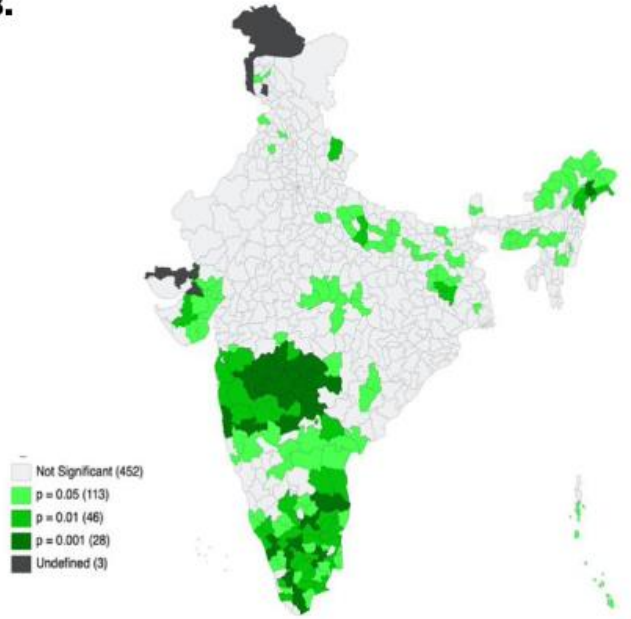

C.

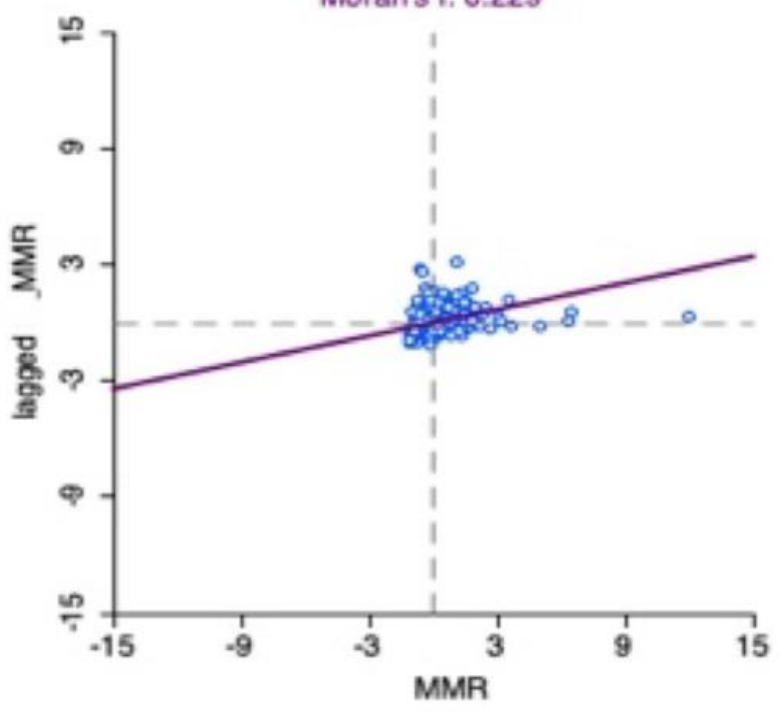


medRxiv preprint doi: https://doi.org/10.1101/2021.09.28.21264229; this version posted October 15, 2021. The copyright holder for this preprint (which was not certified by peer review) is the author/funder, who has granted medRxiv a license to display the preprint in All rights reserved. No reuse allowed without permission.

Figure 4. Percentage of reported live births out of estimated live births by states in HMIS, 2017-19.

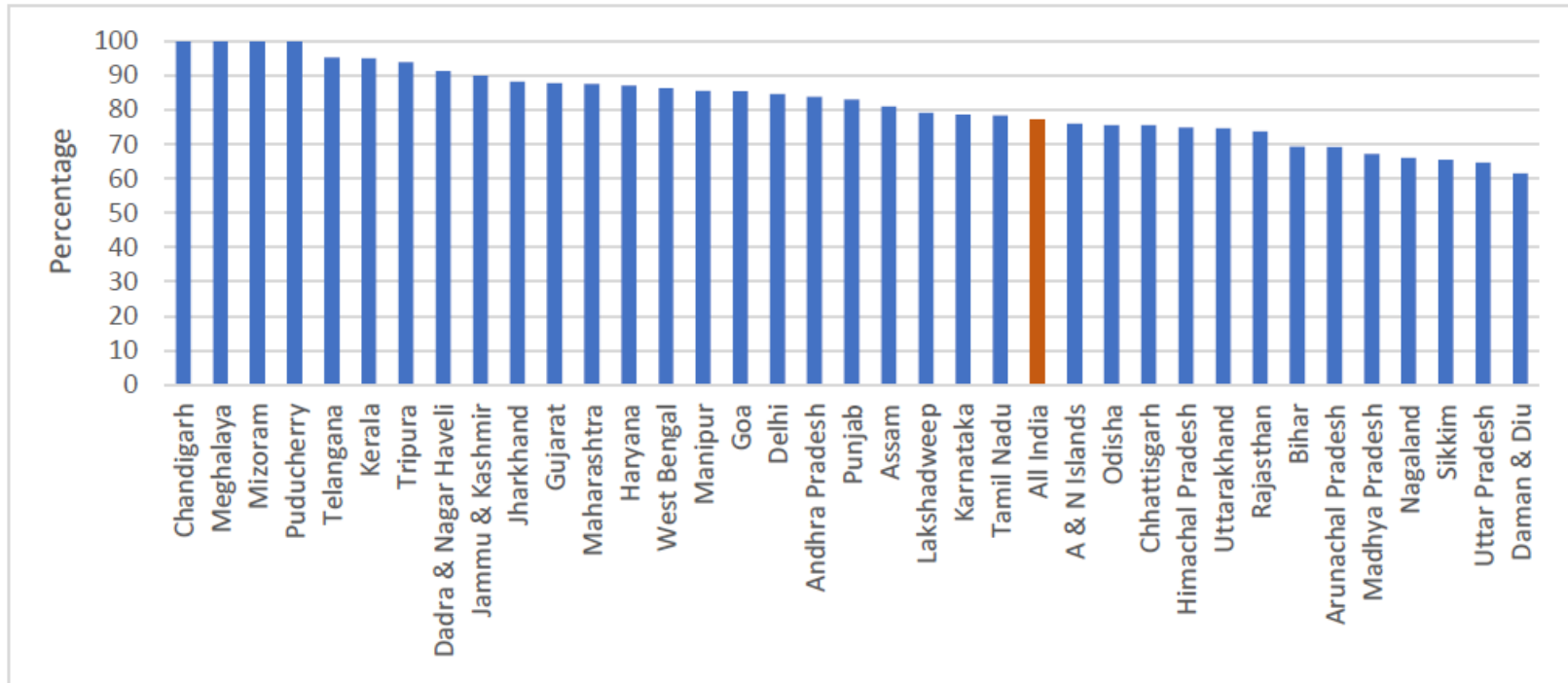


medRxiv preprint doi: https://doi.org/10.1101/2021.09.28.21264229; this version posted October 15, 2021. The copyright holder for this preprint (which was not certified by peer review) is the author/funder, who has granted medRxiv a license to display the preprint in All rights reserved. No reuse allowed without permission.

Figure 5. Correspondence between MMR estimates from SRS and HMIS.

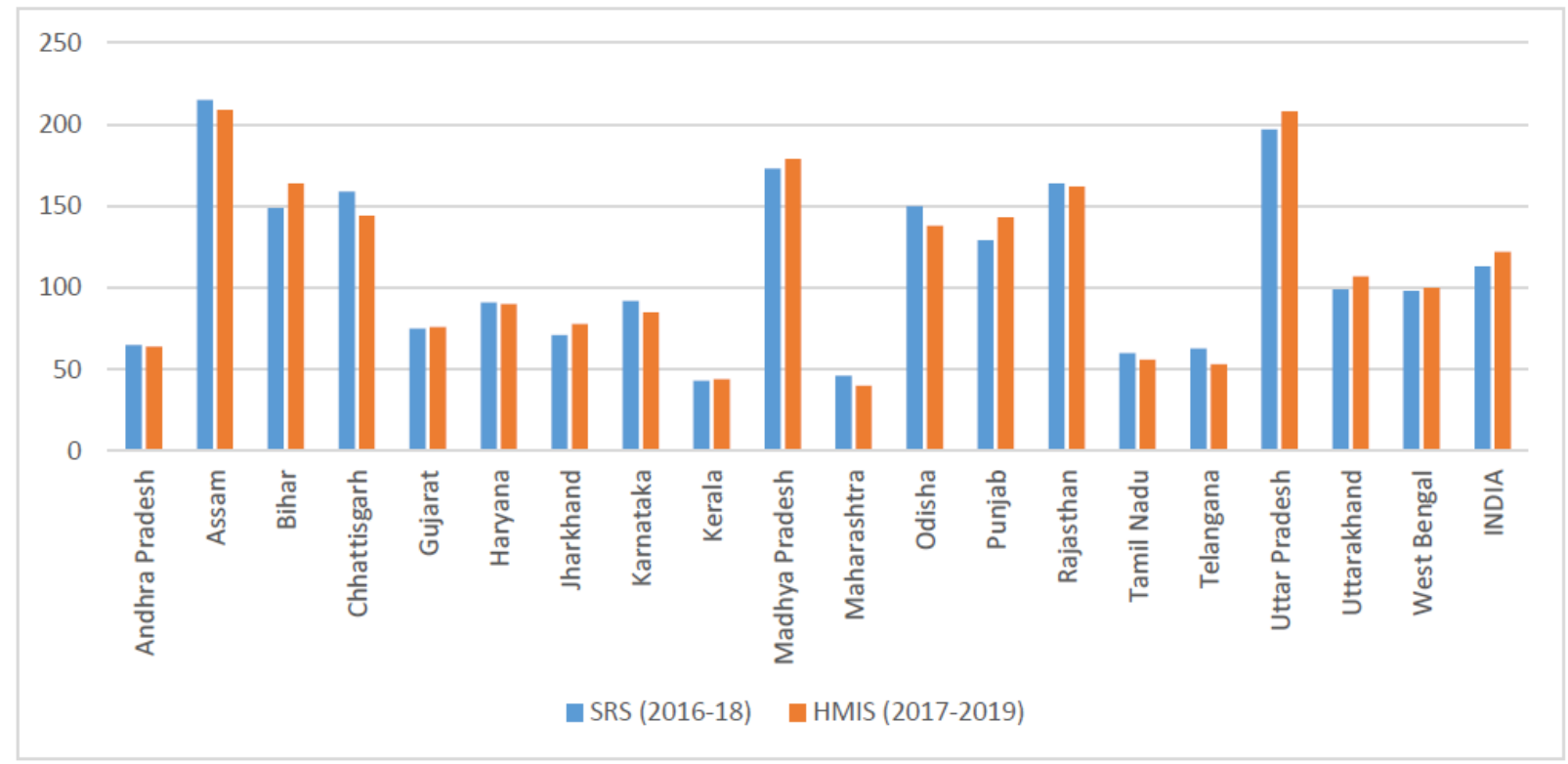


medRxiv preprint doi: https://doi.org/10.1101/2021.09.28.21264229; this version posted October 15, 2021. The copyright holder for this preprint (which was not certified by peer review) is the author/funder, who has granted medRxiv a license to display the preprint in All rights reserved. No reuse allowed without permission.

Figure 6. Correlation between IMR estimates from SRS and MMR estimates from HMIS.

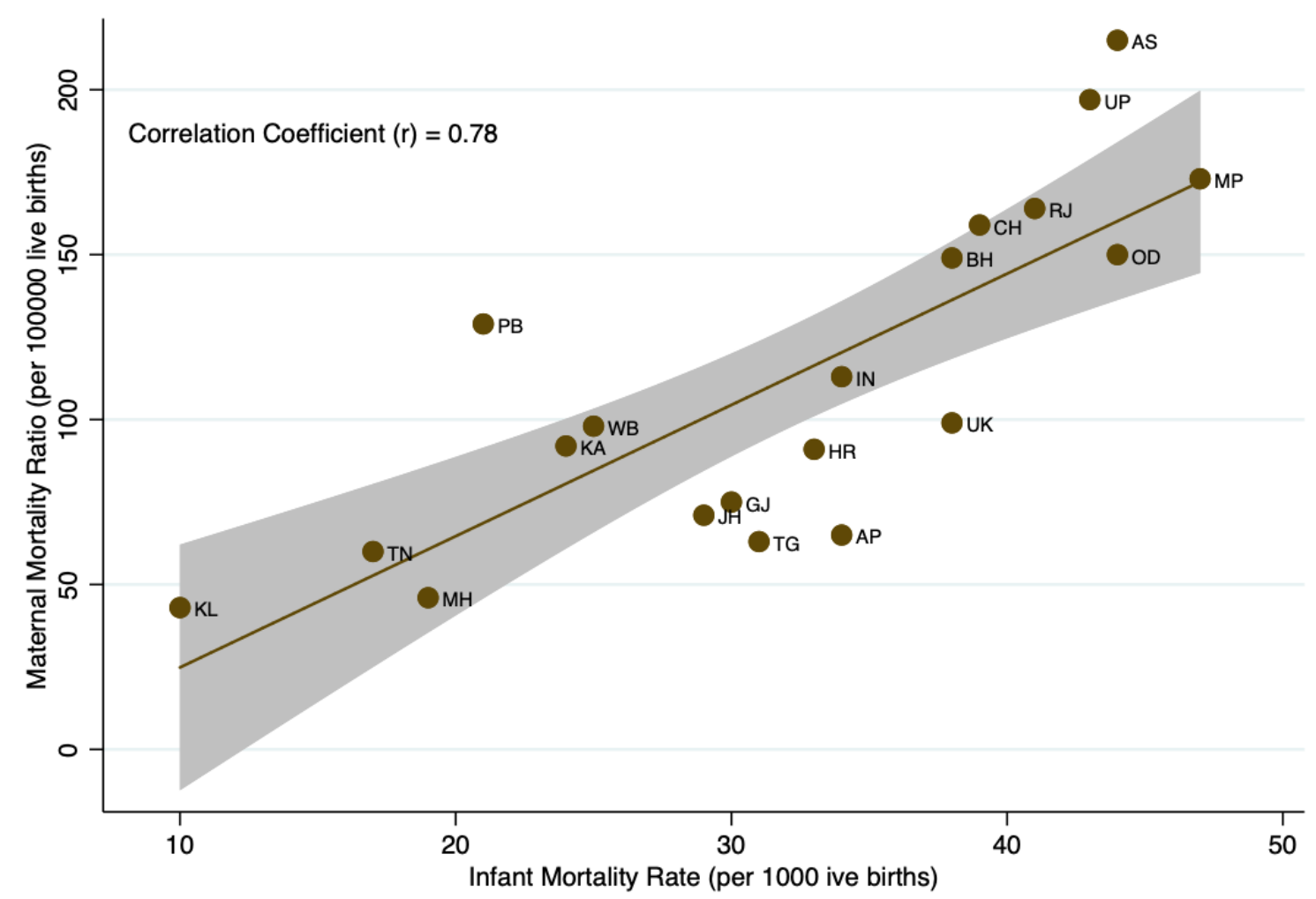


medRxiv preprint doi: https://doi.org/10.1101/2021.09.28.21264229; this version posted October 15, 2021. The copyright holder for this preprint (which was not certified by peer review) is the author/funder, who has granted medRxiv a license to display the preprint in perpetuity.

All rights reserved. No reuse allowed without permission.

\section{Tables}

Table 1. Description of the study variables

\begin{tabular}{ll}
\hline Variable & Definition \\
\hline MMR & Death of women due to pregnancy or within 42 days of termination of \\
& pregnancy, irrespective of the duration and site of the pregnancy, from any \\
& cause related to or aggravated by the pregnancy or its management but not \\
& from accidental or incidental causes. Maternal Mortality Ratio (MMR) is \\
& measured as deaths for 100000 live births.
\end{tabular}

HII

4 or more ANCs

PNCs

Institutional delivery

Contraception

BMI

Anaemic

Mean age at first marriage

Mean age at first

birth

Sex ratio at birth

(SRB)

Mean children ever

born (CEB)

10 or more years of schooling

Average household size

Urban Population

Poor household economic status
Multidimensional measure calculated using information collected for rural health infrastructures on several items: number of district hospitals, Community Health Centers (CHCs), Primary Health Centers (PHCs), Sub-Centers (SCs), doctors, nurses, auxiliary nurse midwife (ANM), accredited Social Health Activist (ASHA), Anganwadi Worker (AWW) per 1000 population. We used the model of HDI for estimating dimension-free numbers then aggregated them to generate Health Infrastructure Index (HII). The HII is adjusted for the share of the urban population in ordered to give weightage to urban health infrastructure (especially private health infrastructure). Weight is equivalent to the share of the urban population in the district.

Percentage of women who received four or more antenatal care services.

Percentage of women who received postnatal care within 48 hours.

Percentage of women delivered a child in hospital settings.

Percentage of women currently using any modern method of contraception

Body Mass Index (BMI) is the height for weight score of adult women in the age group 15-49 years.

Haemoglobin levels below ( $<12 \mathrm{mg} / \mathrm{dl}$ for non-pregnant and $<11 \mathrm{mg} / \mathrm{dl}$ for pregnant) are considered anaemic.

Age at first marriage as reported by women in years

Age at first birth as reported by women in years

Number of girls per 1000 boys at the time of birth

Mean number of children ever born per woman

Percentage of women who have completed 10 years or more schooling.

The average number of persons living in a household

Share of the urban population in a district

Share of poor households derived from the wealth index. The wealth index is derived by assigning scores based on the number and kinds of consumer goods they own, ranging from a television to a bicycle or car, and housing characteristics such as the source of drinking water, toilet facilities, and flooring materials. These scores are derived using principal component analysis. National wealth quintiles are compiled by assigning the household score to each usual (de jure) household member, ranking each person in the household population by their score, and then dividing the distribution into five equal categories, each with 20 percent of the population. We have considered the first two quintiles as relatively poor households ${ }^{17}$.
Data source

Authors estimation from HMIS

Author's estimation from Rural Health Statistics reports of India.

Authors estimation from NFHS (2015-16)

Authors estimation from NFHS (2015-16)

Authors estimation from NFHS (2015-16)

Authors estimation from NFHS (2015-16)

Authors estimation from NFHS (2015-16)

Authors estimation from NFHS (2015-16)

Authors estimation from NFHS (2015-16)

Authors estimation from NFHS (2015-16)

Authors estimation from NFHS (2015-16)

Authors estimation from NFHS (2015-16)

Authors estimation from NFHS (2015-16)

Authors estimation from NFHS (2015-16)

Authors estimation from NFHS (2015-16)

Authors estimation from NFHS (2015-16) 
medRxiv preprint doi: https://doi.org/10.1101/2021.09.28.21264229; this version posted October 15, 2021. The copyright holder for this preprint (which was not certified by peer review) is the author/funder, who has granted medRxiv a license to display the preprint in perpetuity.

All rights reserved. No reuse allowed without permission.

Table 2. Descriptive statistics of the study variables

\begin{tabular}{lccccc}
\hline Variable & Obs & Mean & Std.Dev. & Min & Max \\
\hline Maternal Mortality Ratio & 639 & 142.21 & 127.84 & 0 & 1671 \\
HII & 640 & 0.540 & 0.37 & 0.09 & 5.55 \\
4 or more ANCs (\%) & 640 & 52.46 & 26.01 & 0.85 & 99.14 \\
PNCs within 48 hours of delivery (\%) & 640 & 62.71 & 17.70 & 0. & 100. \\
Institutional delivery (\%) & 640 & 80.34 & 16.61 & 10.25 & 100 \\
Contraception (\%) & 640 & 50.84 & 17.16 & 2.73 & 84.81 \\
Body Mass Index & 640 & 17.62 & 8.76 & 1.17 & 45.06 \\
Anaemic (\%) & 640 & 51.58 & 12.09 & 13.85 & 82.77 \\
Mean age at Marriage & 640 & 18.62 & 1.36 & 15.64 & 23.38 \\
Mean age at first birth & 640 & 20.60 & 1.02 & 18.24 & 24.99 \\
Mean Children Ever Born & 640 & 2.46 & 0.44 & 1.57 & 3.82 \\
10 or more years of schooling (\%) & 640 & 28.13 & 14.26 & 5.6 & 86.47 \\
Sex Ratio at Birth & 626 & 925.11 & 110.86 & 600 & 1537 \\
Average household size & 640 & 5.68 & 0.76 & 3.98 & 8.45 \\
Scheduled Castes/Tribes Population & 640 & 38.16 & 23.27 & 0.70 & 100 \\
(\%) & & & & & \\
Urban Population (\%) & 640 & 27.33 & 21.66 & 0 & 100 \\
Poor households (\%) & 640 & 40.65 & 25.73 & 0.12 & 90.55 \\
\hline
\end{tabular}

Note: Obs. - observations, Std.Dev.- Standard deviation, Min- Minimum, Max- Maximum, ANC - Antenatal care, PNC - Postnatal care 
medRxiv preprint doi: https://doi.org/10.1101/2021.09.28.21264229; this version posted October $15,2021$. The copyright holder for this preprint (which was not certified by peer review) is the author/funder, who has granted medRxiv a license to display the preprint in All rights reserved. No reuse allowed without permission.

Table 3. Log-linear regression estimates: correlates of maternal mortality ratio in India
(1)
(2)
(3)
(4)
(5)
(6)

VARIABLES Model 1

HII

4 or more ANCs

PNCs within 48 hours of

delivery

Institutional delivery

Age at marriage

Age at first birth

Contraception use

Children ever born

BMI

Anaemic

10 or more years of schooling

Sex ratio at birth

Average household size

SC/ST population

Urban population

Poor household economic

status

District dummy

$$
-0.551 * * *
$$

(0.106)

$$
\begin{array}{cc}
-0.273 * * * & -0.0477 \\
(0.102) & (0.109) \\
-0.211 & -0.279 *
\end{array}
$$

(0.162) (0.159)

$0.323 \quad 0.316$

(0.299)

(0.293)

Model 3

$-1.662$

(2.346)

7.905**

(3.094)

0.219*

(0.120)

$1.822 * * *$

(0.332)

$0.437^{* * *}$

(0.113)

0.223

(0.204) Model 4

Model 5

Model 6

\section{$-0.494 * * * \quad-0.535 * * *$}

(0.154)

(0.155)

$0.181 \quad 0.142$

(0.134) (0.137)

$-0.379 * * \quad-0.370 * *$

(0.157) (0.158)

$0.386 \quad 0.485$

(0.324) (0.325)

$\begin{array}{ll}-1.241 & 0.355\end{array}$

(2.767) (2.848)

$8.853^{* *} \quad 7.431^{* *}$

(3.537)

(3.591)

$0.152 \quad 0.134$

(0.132) (0.132)

$1.944 * * * \quad 1.589 * * *$

(0.444) (0.596)

$0.406 * * * \quad 0.357 * * *$

$(0.134) \quad(0.138)$

$0.303 \quad 0.253$

$(0.200) \quad(0.201)$
$0.437 * *$ $-0.437^{* * *}$ (0.155)

$-1.218 * * * \quad-1.078 * * * \quad-1.073 * * *$

$\begin{array}{lll}(0.416) & (0.401) & (0.400)\end{array}$

$-0.0438$

(0.594)

$\begin{array}{lll}-0.0144 & 0.188 * * & 0.146\end{array}$

$\begin{array}{lll}(0.0866) & (0.0933) \quad(0.0943)\end{array}$

$0.0412 \quad 0.287^{* * *} \quad 0.326^{* * *}$

$\begin{array}{lll}(0.0767) & (0.0930) & (0.0939)\end{array}$

$0.215^{* * *} \quad 0.0195 \quad-0.0464$

$\begin{array}{lll}(0.0565) & (0.0810) \quad(0.0862)\end{array}$

Yes Yes

\begin{tabular}{lcccccc} 
Constant & $4.987^{* * *}$ & $4.013^{* * *}$ & $-19.06^{* * *}$ & $12.03^{* * *}$ & $-18.74 * * *$ & $-17.08^{* * *}$ \\
& $(1.010)$ & $(1.008)$ & $(4.442)$ & $(2.868)$ & $(5.471)$ & $(5.487)$ \\
Observations & 638 & 638 & 640 & 623 & 621 & 621 \\
R-squared & 0.018 & 0.058 & 0.110 & 0.042 & 0.176 & 0.187 \\
\hline
\end{tabular}

Note: ANC - Antenatal care, PNC - Postnatal care, SC/ST- Scheduled Caste and Tribes, BMI-Body Mass Index; Robust standard errors in parentheses, $* * * p<0.01, * * p<0.05, * p<0.1$ 


\section{Supporting Information}

Supplementary Table 1. STROBE Checklist. STROBE, strengthening the reporting of observational studies or cross-sectional studies in epidemiology

\begin{tabular}{|c|c|c|c|}
\hline & $\begin{array}{c}\text { Item } \\
\text { No }\end{array}$ & Recommendation & $\begin{array}{l}\text { Page } \\
\text { No }\end{array}$ \\
\hline \multirow[t]{2}{*}{ Title and abstract } & \multirow[t]{2}{*}{1} & $\begin{array}{l}\text { (a) Indicate the study's design with a commonly used term in } \\
\text { the title or the abstract }\end{array}$ & Page no. 1 \\
\hline & & $\begin{array}{l}\text { (b) Provide in the abstract an informative and balanced } \\
\text { summary of what was done and what was found }\end{array}$ & Page no. 1 \\
\hline
\end{tabular}

\section{Introduction}

\begin{tabular}{|c|c|c|c|}
\hline Background/rationale & 2 & $\begin{array}{l}\text { Explain the scientific background and rationale for the } \\
\text { investigation being reported }\end{array}$ & Page no. 3 \\
\hline Objectives & 3 & State-specific objectives, including any prespecified hypotheses & Page no. 4 \\
\hline \multicolumn{4}{|l|}{ Methods } \\
\hline Study design & 4 & Present key elements of study design early in the paper & Page no. 4 \\
\hline Setting & 5 & $\begin{array}{l}\text { Describe the setting, locations, and relevant dates, including } \\
\text { periods of recruitment, exposure, follow-up, and data collection }\end{array}$ & Page no. 4 \\
\hline Participants & 6 & $\begin{array}{l}\text { (a) Give the eligibility criteria, and the sources and methods of } \\
\text { selection of participants }\end{array}$ & Page no. 4 \\
\hline Variables & 7 & $\begin{array}{l}\text { Clearly define all outcomes, exposures, predictors, potential } \\
\text { confounders, and effect modifiers. Give diagnostic criteria, if } \\
\text { applicable }\end{array}$ & Page no. 5 \\
\hline $\begin{array}{l}\text { Data sources/ } \\
\text { measurement }\end{array}$ & $8^{*}$ & $\begin{array}{l}\text { For each variable of interest, give sources of data and details of } \\
\text { methods of assessment (measurement). Describe comparability } \\
\text { of assessment methods if there is more than one group }\end{array}$ & Page no. 4 and 5 \\
\hline Bias & 9 & Describe any efforts to address potential sources of bias & Page no. 4 \\
\hline Study size & 10 & Explain how the study size was arrived at & Page no. 4 \\
\hline $\begin{array}{l}\text { Quantitative } \\
\text { variables }\end{array}$ & 11 & $\begin{array}{l}\text { Explain how quantitative variables were handled in the } \\
\text { analyses. If applicable, describe which groupings were chosen } \\
\text { and why }\end{array}$ & Page no. 5 \\
\hline \multirow[t]{5}{*}{ Statistical methods } & \multirow[t]{5}{*}{12} & $\begin{array}{l}\text { (a) Describe all statistical methods, including those used to } \\
\text { control for confounding }\end{array}$ & Page no. 5 and 6 \\
\hline & & $\begin{array}{l}\text { (b) Describe any methods used to examine subgroups and } \\
\text { interactions }\end{array}$ & Page no. 5 and 6 \\
\hline & & (c) Explain how missing data were addressed & Page no. 5 and 6 \\
\hline & & $\begin{array}{l}\text { (d) If applicable, describe analytical methods taking account of } \\
\text { sampling strategy }\end{array}$ & Page no. 5 and 6 \\
\hline & & (e $)$ Describe any sensitivity analyses & Page no. 8 \\
\hline \multicolumn{4}{|l|}{ Results } \\
\hline \multirow[t]{2}{*}{ Participants } & $13 *$ & $\begin{array}{l}\text { (a) Report numbers of individuals at each stage of study—eg } \\
\text { numbers potentially eligible, examined for eligibility, confirmed } \\
\text { eligible, included in the study, completing follow-up, and } \\
\text { analysed }\end{array}$ & NA \\
\hline & & (b) Give reasons for non-participation at each stage & NA \\
\hline
\end{tabular}


medRxiv preprint doi: https://doi.org/10.1101/2021.09.28.21264229; this version posted October 15, 2021. The copyright holder for this preprint (which was not certified by peer review) is the author/funder, who has granted medRxiv a license to display the preprint in perpetuity.

All rights reserved. No reuse allowed without permission.

(c) Consider use of a flow diagram

\begin{tabular}{|c|c|c|c|}
\hline \multirow[t]{2}{*}{ Descriptive data } & \multirow[t]{2}{*}{$14^{*}$} & $\begin{array}{l}\text { (a) Give characteristics of study participants (eg demographic, } \\
\text { clinical, social) and information on exposures and potential } \\
\text { confounders }\end{array}$ & $\begin{array}{l}\text { Page no. } 6 \text {, Table } 1 \\
\text { and Table } 2\end{array}$ \\
\hline & & $\begin{array}{l}\text { (b) Indicate number of participants with missing data for each } \\
\text { variable of interest }\end{array}$ & Page no. 6, Table 1. \\
\hline Outcome data & $15^{*}$ & Report numbers of outcome events or summary measures & Page no. 6, Table 1. \\
\hline \multirow[t]{3}{*}{ Main results } & \multirow[t]{3}{*}{16} & $\begin{array}{l}\text { (a) Give unadjusted estimates and, if applicable, confounder- } \\
\text { adjusted estimates and their precision (eg, } 95 \% \text { confidence } \\
\text { interval). Make clear which confounders were adjusted for and } \\
\text { why they were included }\end{array}$ & $\begin{array}{l}\text { Page no. } 6 \text { to Page } \\
\text { no. } 9 . \text { Table } 3 \text { and } \\
\text { Figure } 1,2,3\end{array}$ \\
\hline & & $\begin{array}{l}\text { (b) Report category boundaries when continuous variables were } \\
\text { categorized }\end{array}$ & NA \\
\hline & & $\begin{array}{l}\text { (c) If relevant, consider translating estimates of relative risk into } \\
\text { absolute risk for a meaningful time period }\end{array}$ & NA \\
\hline Other analyses & 17 & $\begin{array}{l}\text { Report other analyses done-eg analyses of subgroups and } \\
\text { interactions, and sensitivity analyses }\end{array}$ & $\begin{array}{l}\text { Page no. } 8 \text {, Figure } 4 \\
\text { and Figure } 5 .\end{array}$ \\
\hline
\end{tabular}

\begin{tabular}{|c|c|c|c|}
\hline \multicolumn{4}{|l|}{ Discussion } \\
\hline Key results & 18 & Summarise key results with reference to study objectives & Page no. 10 \\
\hline Limitations & 19 & $\begin{array}{l}\text { Discuss limitations of the study, taking into account sources of } \\
\text { potential bias or imprecision. Discuss both direction and } \\
\text { magnitude of any potential bias }\end{array}$ & Page no. 10 \\
\hline Interpretation & 20 & $\begin{array}{l}\text { Give a cautious overall interpretation of results considering } \\
\text { objectives, limitations, multiplicity of analyses, results from } \\
\text { similar studies, and other relevant evidence }\end{array}$ & Page no. 10 \\
\hline Generalisability & 21 & $\begin{array}{l}\text { Discuss the generalisability (external validity) of the study } \\
\text { results }\end{array}$ & Page no. 10 and 11 \\
\hline \multicolumn{4}{|c|}{ Other information } \\
\hline Funding & 22 & $\begin{array}{l}\text { Give the source of funding and the role of the funders for the } \\
\text { present study and, if applicable, for the original study on which } \\
\text { the present article is based }\end{array}$ & Page no. 11. \\
\hline
\end{tabular}

*Give information separately for exposed and unexposed groups.

Note: An Explanation and Elaboration article discusses each checklist item and gives methodological background and published examples of transparent reporting. The STROBE checklist is best used in conjunction with this article (freely available on the Web sites of PLoS Medicine at http://www.plosmedicine.org/, Annals of Internal Medicine at http://www.annals.org/, and Epidemiology at http://www.epidem.com/). Information on the STROBE Initiative is available at www.strobe-statement.org. 
medRxiv preprint doi: https://doi.org/10.1101/2021.09.28.21264229; this version posted October 15, 2021. The copyright holder for this preprint (which was not certified by peer review) is the author/funder, who has granted medRxiv a license to display the preprint in

All rights reserved. No reuse allowed without permission.

Supplementary Table 2. State-wise estimates of MMR from SRS and HMIS

\begin{tabular}{|c|c|c|c|c|}
\hline $\begin{array}{l}\text { Sr. } \\
\text { No }\end{array}$ & States & SRS (2014-16) & SRS (2016-18) & $\begin{array}{c}\text { HMIS (2017- } \\
2019)\end{array}$ \\
\hline 1 & A \& N Islands & & & 275 \\
\hline 2 & Andhra Pradesh & 74 & 65 & 64 \\
\hline 3 & Arunachal Pradesh & & & 284 \\
\hline 4 & Assam & 237 & 215 & 209 \\
\hline 5 & Bihar & 165 & 149 & 164 \\
\hline 6 & Chandigarh & & & 15 \\
\hline 7 & Chhattisgarh* & & 159 & 144 \\
\hline 8 & Dadra \& Nagar Haveli & & & 61 \\
\hline 9 & Daman \& Diu & & & 48 \\
\hline 10 & Delhi & & & 162 \\
\hline 11 & Goa & & & 91 \\
\hline 12 & Gujarat & 91 & 75 & 76 \\
\hline 13 & Haryana & 101 & 91 & 90 \\
\hline 14 & Himachal Pradesh & & & 127 \\
\hline 15 & Jammu \& Kashmir & & & 151 \\
\hline 16 & Jharkhand* & & 71 & 78 \\
\hline 17 & Karnataka & 108 & 92 & 85 \\
\hline 18 & Kerala & 46 & 43 & 44 \\
\hline 19 & Lakshadweep & & & 208 \\
\hline 20 & Madhya Pradesh & 173 & 173 & 179 \\
\hline 21 & Maharashtra & 61 & 46 & 40 \\
\hline 22 & Manipur & & & 282 \\
\hline 23 & Meghalaya & & & 266 \\
\hline 24 & Mizoram & & & 131 \\
\hline 25 & Nagaland & & & 143 \\
\hline 26 & Odisha & 180 & 150 & 138 \\
\hline 27 & Puducherry & & & 41 \\
\hline 28 & Punjab & 122 & 129 & 143 \\
\hline 29 & Rajasthan & 199 & 164 & 162 \\
\hline 30 & Sikkim & & & 228 \\
\hline 31 & Tamil Nadu & 66 & 60 & 56 \\
\hline 32 & Telangana & 81 & 63 & 53 \\
\hline 33 & Tripura & & & 119 \\
\hline 34 & Uttar Pradesh & 201 & 197 & 208 \\
\hline 35 & Uttarakhand* & & 99 & 107 \\
\hline \multirow[t]{2}{*}{36} & West Bengal & 101 & 98 & 100 \\
\hline & INDIA & 130 & 113 & 122 \\
\hline
\end{tabular}

*Separate MMR estimates for these states are not available as they were merged with their parent states for SRS bulletin 2014-16 
medRxiv preprint doi: https://doi.org/10.1101/2021.09.28.21264229; this version posted October 15, 2021. The copyright holder for this preprint (which was not certified by peer review) is the author/funder, who has granted medRxiv a license to display the preprint in perpetuity.

All rights reserved. No reuse allowed without permission.

Supplementary Table 3. District-wise Estimates of MMR from HMIS

\begin{tabular}{|c|c|c|c|}
\hline $\begin{array}{l}\text { Sr. } \\
\text { No. }\end{array}$ & District & State/Union Territory & MMR \\
\hline 1 & Nicobars & Andaman \& Nicobar & 101 \\
\hline 2 & North \& Middle Andaman & Andaman \& Nicobar & 605 \\
\hline 3 & South Andaman & Andaman \& Nicobar & 159 \\
\hline 4 & Anantapur & Andhra Pradesh & 45 \\
\hline 5 & Chittoor & Andhra Pradesh & 57 \\
\hline 6 & East Godavari & Andhra Pradesh & 79 \\
\hline 7 & Guntur & Andhra Pradesh & 89 \\
\hline 8 & Krishna & Andhra Pradesh & 74 \\
\hline 9 & Kurnool & Andhra Pradesh & 87 \\
\hline 10 & Prakasam & Andhra Pradesh & 38 \\
\hline 11 & Sri Potti Sriramulu Nellore & Andhra Pradesh & 40 \\
\hline 12 & Srikakulam & Andhra Pradesh & 32 \\
\hline 13 & Visakhapatnam & Andhra Pradesh & 129 \\
\hline 14 & Vizianagaram & Andhra Pradesh & 38 \\
\hline 15 & West Godavari & Andhra Pradesh & 29 \\
\hline 16 & Y.S.R. & Andhra Pradesh & 40 \\
\hline 17 & Anjaw & Arunachal Pradesh & 0 \\
\hline 18 & Dibang Valley & Arunachal Pradesh & 0 \\
\hline 19 & Kurung Kumey & Arunachal Pradesh & 0 \\
\hline 20 & Lohit & Arunachal Pradesh & 184 \\
\hline 21 & Lower Dibang Valley & Arunachal Pradesh & 336 \\
\hline 22 & Changlang & Arunachal Pradesh & 0 \\
\hline 23 & East Kameng & Arunachal Pradesh & 284 \\
\hline 24 & East Siang & Arunachal Pradesh & 403 \\
\hline 25 & Lower Subansiri & Arunachal Pradesh & 0 \\
\hline 26 & Papum Pare & Arunachal Pradesh & 298 \\
\hline 27 & Tawang & Arunachal Pradesh & 364 \\
\hline 28 & Tirap & Arunachal Pradesh & 1671 \\
\hline 29 & Upper Siang & Arunachal Pradesh & 0 \\
\hline 30 & Upper Subansiri & Arunachal Pradesh & 247 \\
\hline 31 & West Kameng & Arunachal Pradesh & 256 \\
\hline 32 & West Siang & Arunachal Pradesh & 0 \\
\hline 33 & Baksa & Assam & 107 \\
\hline 34 & Barpeta & Assam & 150 \\
\hline 35 & Bongaigaon & Assam & 139 \\
\hline 36 & Cachar & Assam & 431 \\
\hline 37 & Chirang & Assam & 170 \\
\hline 38 & Darrang & Assam & 120 \\
\hline 39 & Dhemaji & Assam & 109 \\
\hline 40 & Dhubri & Assam & 186 \\
\hline 41 & Dibrugarh & Assam & 379 \\
\hline 42 & Dima Hasao & Assam & 232 \\
\hline 43 & Goalpara & Assam & 179 \\
\hline 44 & Golaghat & Assam & 296 \\
\hline 45 & Hailakandi & Assam & 169 \\
\hline 46 & Jorhat & Assam & 170 \\
\hline 47 & Kamrup & Assam & 409 \\
\hline
\end{tabular}




\begin{tabular}{|c|c|c|c|}
\hline 48 & Kamrup Metropolitan & Assam & 143 \\
\hline 49 & Karbi Anglong & Assam & 200 \\
\hline 50 & Karimganj & Assam & 310 \\
\hline 51 & Kokrajhar & Assam & 365 \\
\hline 52 & Lakhimpur & Assam & 73 \\
\hline 53 & Morigaon & Assam & 142 \\
\hline 54 & Nagaon & Assam & 134 \\
\hline 55 & Nalbari & Assam & 88 \\
\hline 56 & Sivasagar & Assam & 141 \\
\hline 57 & Sonitpur & Assam & 246 \\
\hline 58 & Tinsukia & Assam & 81 \\
\hline 59 & Udalguri & Assam & 225 \\
\hline 60 & Araria & Bihar & 103 \\
\hline 61 & Arwal & Bihar & 452 \\
\hline 62 & Aurangabad & Bihar & 98 \\
\hline 63 & Banka & Bihar & 425 \\
\hline 64 & Begusarai & Bihar & 61 \\
\hline 65 & Bhagalpur & Bihar & 787 \\
\hline 66 & Bhojpur & Bihar & 175 \\
\hline 67 & Buxar & Bihar & 312 \\
\hline 68 & Darbhanga & Bihar & 39 \\
\hline 69 & Gaya & Bihar & 163 \\
\hline 70 & Gopalganj & Bihar & 145 \\
\hline 71 & Jamui & Bihar & 197 \\
\hline 72 & Jehanabad & Bihar & 245 \\
\hline 73 & Kaimur (Bhabua) & Bihar & 221 \\
\hline 74 & Katihar & Bihar & 64 \\
\hline 75 & Khagaria & Bihar & 26 \\
\hline 76 & Kishanganj & Bihar & 190 \\
\hline 77 & Lakhisarai & Bihar & 87 \\
\hline 78 & Madhepura & Bihar & 25 \\
\hline 79 & Madhubani & Bihar & 112 \\
\hline 80 & Munger & Bihar & 241 \\
\hline 81 & Muzaffarpur & Bihar & 83 \\
\hline 82 & Nalanda & Bihar & 69 \\
\hline 83 & Nawada & Bihar & 50 \\
\hline 84 & Pashchim Champaran & Bihar & 64 \\
\hline 85 & Patna & Bihar & 544 \\
\hline 86 & Purba Champaran & Bihar & 136 \\
\hline 87 & Purnia & Bihar & 122 \\
\hline 88 & Rohtas & Bihar & 137 \\
\hline 89 & Saharsa & Bihar & 44 \\
\hline 90 & Samastipur & Bihar & 181 \\
\hline 91 & Saran & Bihar & 59 \\
\hline 92 & Sheikhpura & Bihar & 103 \\
\hline 93 & Sheohar & Bihar & 121 \\
\hline 94 & Sitamarhi & Bihar & 42 \\
\hline 95 & Siwan & Bihar & 119 \\
\hline 96 & Supaul & Bihar & 140 \\
\hline 97 & Vaishali & Bihar & 47 \\
\hline
\end{tabular}




\begin{tabular}{cl}
98 & Chandigarh \\
99 & Bastar \\
100 & Bijapur \\
101 & Bilaspur \\
102 & Dakshin Bastar Dantewada \\
103 & Dhamtari \\
104 & Durg \\
105 & Janjgir - Champa \\
106 & Jashpur \\
107 & Kabeerdham \\
108 & Korba \\
109 & Koriya \\
110 & Mahasamund \\
111 & Narayanpur \\
112 & Raigarh \\
113 & Raipur \\
114 & Rajnandgaon \\
115 & Surguja \\
116 & Uttar Bastar Kanker \\
117 & Dadra and Nagar Haveli \\
118 & Daman \\
119 & Diu \\
120 & Central \\
121 & East \\
122 & New \\
123 & North \\
124 & North East \\
125 & North West \\
126 & South \\
127 & South West \\
128 & West \\
129 & North Goa \\
130 & South Goa \\
131 & Ahmadabad \\
132 & Amreli \\
133 & Anand \\
134 & Banas Kantha \\
135 & Bharuch \\
136 & Bhavnagar \\
137 & Dohad \\
138 & Gandhinagar \\
139 & Jamnagar \\
140 & Junagadh \\
141 & Kachchh \\
142 & Kheda \\
143 & Mahesana \\
144 & Narmada \\
145 & Navsari \\
147 & Panch Mahals \\
& Patan \\
\hline 10
\end{tabular}

Chandigarh 15

Chhattisgarh 248

Chhattisgarh 423

Chhattisgarh 121

Chhattisgarh 247

Chhattisgarh 275

Chhattisgarh 98

Chhattisgarh 34

Chhattisgarh 176

Chhattisgarh 89

Chhattisgarh 121

Chhattisgarh 234

Chhattisgarh 136

Chhattisgarh $\quad 184$

Chhattisgarh 202

Chhattisgarh $\quad 143$

Chhattisgarh $\quad 164$

Chhattisgarh 211

Chhattisgarh 220

Dadra and Nagar Haveli $\quad 61$

Daman \& Diu 22

Daman \& Diu 122

Delhi 151

Delhi 270

Delhi 347

Delhi 93

Delhi 153

Delhi 198

Delhi 163

Delhi 32

Delhi 181

Goa 152

Goa 15

Gujarat $\quad 70$

Gujarat $\quad 46$

Gujarat $\quad 112$

Gujarat 46

Gujarat 83

Gujarat $\quad 55$

Gujarat $\quad 50$

Gujarat $\quad 51$

Gujarat $\quad 106$

Gujarat 31

Gujarat $\quad 95$

Gujarat 49

Gujarat 62

Gujarat 80

Gujarat $\quad 58$

Gujarat 101

Gujarat $\quad 80$ 


\begin{tabular}{|c|c|c|c|}
\hline 148 & Porbandar & Gujarat & 78 \\
\hline 149 & Rajkot & Gujarat & 69 \\
\hline 150 & Sabar Kantha & Gujarat & 60 \\
\hline 151 & Surat & Gujarat & 54 \\
\hline 152 & Surendranagar & Gujarat & 71 \\
\hline 153 & Tapi & Gujarat & 84 \\
\hline 154 & The Dangs & Gujarat & 156 \\
\hline 155 & Vadodara & Gujarat & 195 \\
\hline 156 & Valsad & Gujarat & 62 \\
\hline 157 & Ambala & Haryana & 58 \\
\hline 158 & Bhiwani & Haryana & 105 \\
\hline 159 & Faridabad & Haryana & 55 \\
\hline 160 & Fatehabad & Haryana & 121 \\
\hline 161 & Gurgaon & Haryana & 105 \\
\hline 162 & Hisar & Haryana & 86 \\
\hline 163 & Jhajjar & Haryana & 98 \\
\hline 164 & Jind & Haryana & 93 \\
\hline 165 & Kaithal & Haryana & 74 \\
\hline 166 & Karnal & Haryana & 125 \\
\hline 167 & Kurukshetra & Haryana & 82 \\
\hline 168 & Mahendragarh & Haryana & 87 \\
\hline 169 & Mewat & Haryana & 111 \\
\hline 170 & Palwal & Haryana & 120 \\
\hline 171 & Panchkula & Haryana & 35 \\
\hline 172 & Panipat & Haryana & 101 \\
\hline 173 & Rewari & Haryana & 59 \\
\hline 174 & Rohtak & Haryana & 117 \\
\hline 175 & Sirsa & Haryana & 88 \\
\hline 176 & Sonipat & Haryana & 67 \\
\hline 177 & Yamunanagar & Haryana & 93 \\
\hline 178 & Bilaspur & Himachal Pradesh & 183 \\
\hline 179 & Chamba & Himachal Pradesh & 150 \\
\hline 180 & Hamirpur & Himachal Pradesh & 64 \\
\hline 181 & Kangra & Himachal Pradesh & 103 \\
\hline 182 & Kinnaur & Himachal Pradesh & 0 \\
\hline 183 & Kullu & Himachal Pradesh & 223 \\
\hline 184 & Lahul \& Spiti & Himachal Pradesh & 0 \\
\hline 185 & Mandi & Himachal Pradesh & 92 \\
\hline 186 & Shimla & Himachal Pradesh & 109 \\
\hline 187 & Sirmaur & Himachal Pradesh & 219 \\
\hline 188 & Solan & Himachal Pradesh & 167 \\
\hline 189 & Una & Himachal Pradesh & 102 \\
\hline 190 & Anantnag & $\mathrm{J} \& \mathrm{~K}$ & 97 \\
\hline 191 & Badgam & $\mathrm{J} \& \mathrm{~K}$ & 194 \\
\hline 192 & Bandipore & $\mathrm{J} \& \mathrm{~K}$ & 330 \\
\hline 193 & Baramula & $\mathrm{J} \& \mathrm{~K}$ & 182 \\
\hline 194 & Doda & $\mathrm{J} \& \mathrm{~K}$ & 15 \\
\hline 195 & Ganderbal & $\mathrm{J} \& \mathrm{~K}$ & 53 \\
\hline 196 & Jammu & $\mathrm{J} \& \mathrm{~K}$ & 120 \\
\hline 197 & Kargil & $\mathrm{J} \& \mathrm{~K}$ & 41 \\
\hline
\end{tabular}




\begin{tabular}{|c|c|}
\hline 198 & Kathua \\
\hline 199 & Kishtwar \\
\hline 200 & Kulgam \\
\hline 201 & Kupwara \\
\hline 202 & Leh(Ladakh) \\
\hline 203 & Pulwama \\
\hline 204 & Punch \\
\hline 205 & Rajouri \\
\hline 206 & Ramban \\
\hline 207 & Reasi \\
\hline 208 & Samba \\
\hline 209 & Shupiyan \\
\hline 210 & Srinagar \\
\hline 211 & Udhampur \\
\hline 212 & Bokaro \\
\hline 213 & Chatra \\
\hline 214 & Deoghar \\
\hline 215 & Dhanbad \\
\hline 216 & Dumka \\
\hline 217 & Garhwa \\
\hline 218 & Giridih \\
\hline 219 & Godda \\
\hline 220 & Gumla \\
\hline 221 & Hazaribagh \\
\hline 222 & Jamtara \\
\hline 223 & Khunti \\
\hline 224 & Kodarma \\
\hline 225 & Latehar \\
\hline 226 & Lohardaga \\
\hline 227 & Pakur \\
\hline 228 & Palamu \\
\hline 229 & Pashchimi Singhbhum \\
\hline 230 & Purbi Singhbhum \\
\hline 231 & Ramgarh \\
\hline 232 & Ranchi \\
\hline 233 & Sahibganj \\
\hline 234 & Saraikela-Kharsawan \\
\hline 235 & Simdega \\
\hline 236 & Bagalkot \\
\hline 237 & Bangalore \\
\hline 238 & Bangalore Rural \\
\hline 239 & Belgaum \\
\hline 240 & Bellary \\
\hline 241 & Bidar \\
\hline 242 & Bijapur \\
\hline 243 & Chamarajanagar \\
\hline 244 & Chikkaballapura \\
\hline 245 & Chikmagalur \\
\hline 246 & Chitradurga \\
\hline 247 & Dakshina Kannada \\
\hline
\end{tabular}

$\mathrm{J} \& \mathrm{~K}$

$\mathrm{J} \& \mathrm{~K}$

$\mathrm{J} \& \mathrm{~K}$

$\mathrm{J} \& \mathrm{~K}$

$\mathrm{J} \& \mathrm{~K}$

$\mathrm{J} \& \mathrm{~K}$

$\mathrm{J} \& \mathrm{~K}$

$\mathrm{J} \& \mathrm{~K}$

$\mathrm{J} \& \mathrm{~K}$

$\mathrm{J} \& \mathrm{~K}$

$\mathrm{J} \& \mathrm{~K}$

$\mathrm{J} \& \mathrm{~K}$

962

$\mathrm{J} \& \mathrm{~K}$

137

$\mathrm{J} \& \mathrm{~K}$

Jharkhand

30

Jharkhand 56

Jharkhand 56

Jharkhand 29

Jharkhand 109

Jharkhand 51

Jharkhand 39

Jharkhand 47

Jharkhand 158

Jharkhand 73

Jharkhand 83

Jharkhand 144

Jharkhand 50

Jharkhand 115

Jharkhand 118

Jharkhand 126

Jharkhand 70

Jharkhand 111

Jharkhand 59

Jharkhand 65

Jharkhand 78

Jharkhand 77

Jharkhand 77

Jharkhand 108

Karnataka 48

Karnataka 59

Karnataka 78

Karnataka 104

Karnataka $\quad 155$

Karnataka 53

Karnataka $\quad 55$

Karnataka 44

Karnataka 63

Karnataka 58

Karnataka $\quad 89$

Karnataka 89 


$\begin{array}{ll}248 & \text { Davanagere } \\ 249 & \text { Dharwad } \\ 250 & \text { Gadag } \\ 251 & \text { Gulbarga } \\ 252 & \text { Hassan } \\ 253 & \text { Haveri } \\ 254 & \text { Kodagu } \\ 255 & \text { Kolar } \\ 256 & \text { Koppal } \\ 257 & \text { Mandya } \\ 258 & \text { Mysore } \\ 259 & \text { Raichur } \\ 260 & \text { Ramanagara } \\ 261 & \text { Shimoga } \\ 262 & \text { Tumkur } \\ 263 & \text { Udupi } \\ 264 & \text { Uttara Kannada } \\ 265 & \text { Yadgir } \\ 266 & \text { Alappuzha } \\ 267 & \text { Ernakulam } \\ 268 & \text { Idukki } \\ 269 & \text { Kannur } \\ 270 & \text { Kasargod } \\ 271 & \text { Kollam } \\ 272 & \text { Kottayam } \\ 273 & \text { Kozhikode } \\ 274 & \text { Malappuram } \\ 275 & \text { Palakkad } \\ 276 & \text { Pathanamthitta } \\ 277 & \text { Thiruvananthapuram } \\ 278 & \text { Thrissur } \\ 279 & \text { Wayanad } \\ 280 & \text { Lakshdweep } \\ 281 & \text { Alirajpur } \\ 282 & \text { Anuppur } \\ 283 & \text { Ashoknagar } \\ 284 & \text { Balaghat } \\ 285 & \text { Barwani } \\ 286 & \text { Betul } \\ 287 & \text { Bhind } \\ 288 & \text { Bhopal } \\ 289 & \text { Burhanpur } \\ 290 & \text { Chhatarpur } \\ 291 & \text { Chhindwara } \\ 292 & \text { Damoh } \\ 293 & \text { Datia } \\ 295 & \text { Dewas } \\ 296 & \text { Dinar } \\ 297 & \text { Guna } \\ & \end{array}$

Karnataka 108

Karnataka 209

Karnataka 65

Karnataka 165

Karnataka 60

Karnataka 79

Karnataka 64

Karnataka 56

Karnataka 70

Karnataka 73

Karnataka 85

Karnataka 127

Karnataka $\quad 81$

Karnataka 95

Karnataka 86

Karnataka $\quad 83$

Karnataka 46

Karnataka 74

Kerala 13

Kerala 34

Kerala 45

Kerala 19

Kerala 24

Kerala 101

Kerala 118

Kerala 65

Kerala 37

Kerala 20

Kerala 13

Kerala 28

Kerala 43

Kerala 61

Lakshdweep 208

Madhya Pradesh 191

Madhya Pradesh 392

Madhya Pradesh 243

Madhya Pradesh 181

Madhya Pradesh 187

Madhya Pradesh 169

Madhya Pradesh 134

Madhya Pradesh 359

Madhya Pradesh 252

Madhya Pradesh 92

Madhya Pradesh 199

Madhya Pradesh 161

Madhya Pradesh 161

Madhya Pradesh 105

Madhya Pradesh 131

Madhya Pradesh 169

Madhya Pradesh 80 


\begin{tabular}{|c|c|}
\hline 298 & Gwalior \\
\hline 299 & Harda \\
\hline 300 & Hoshangabad \\
\hline 301 & Indore \\
\hline 302 & Jabalpur \\
\hline 303 & Jhabua \\
\hline 304 & Katni \\
\hline 305 & Khandwa (East Nimar) \\
\hline 306 & Khargone (West Nimar) \\
\hline 307 & Mandla \\
\hline 308 & Mandsaur \\
\hline 309 & Morena \\
\hline 310 & Narsimhapur \\
\hline 311 & Neemuch \\
\hline 312 & Panna \\
\hline 313 & Raisen \\
\hline 314 & Rajgarh \\
\hline 315 & Ratlam \\
\hline 316 & Rewa \\
\hline 317 & Sagar \\
\hline 318 & Satna \\
\hline 319 & Sehore \\
\hline 320 & Seoni \\
\hline 321 & Shahdol \\
\hline 322 & Shajapur \\
\hline 323 & Sheopur \\
\hline 324 & Shivpuri \\
\hline 325 & Sidhi \\
\hline 326 & Singrauli \\
\hline 327 & Tikamgarh \\
\hline 328 & Ujjain \\
\hline 329 & Umaria \\
\hline 330 & Vidisha \\
\hline 331 & Ahmadnagar \\
\hline 332 & Akola \\
\hline 333 & Amravati \\
\hline 334 & Aurangabad \\
\hline 335 & Bhandara \\
\hline 336 & Bid \\
\hline 337 & Buldana \\
\hline 338 & Chandrapur \\
\hline 339 & Dhule \\
\hline 340 & Gadchiroli \\
\hline 341 & Gondiya \\
\hline 342 & Hingoli \\
\hline 343 & Jalgaon \\
\hline 344 & Jalna \\
\hline 345 & Kolhapur \\
\hline 346 & Latur \\
\hline 347 & Mumbai \\
\hline
\end{tabular}

Madhya Pradesh $\quad 134$

Madhya Pradesh 113

Madhya Pradesh 102

Madhya Pradesh 106

Madhya Pradesh 435

Madhya Pradesh 102

Madhya Pradesh 282

Madhya Pradesh 111

Madhya Pradesh $\quad 148$

Madhya Pradesh 208

Madhya Pradesh 97

Madhya Pradesh 123

Madhya Pradesh 437

Madhya Pradesh 157

Madhya Pradesh 206

Madhya Pradesh 171

Madhya Pradesh 81

Madhya Pradesh 89

Madhya Pradesh 181

Madhya Pradesh 235

Madhya Pradesh 155

Madhya Pradesh 79

Madhya Pradesh 204

Madhya Pradesh 302

Madhya Pradesh 97

Madhya Pradesh 170

Madhya Pradesh 108

Madhya Pradesh 219

Madhya Pradesh 149

Madhya Pradesh 97

Madhya Pradesh 153

Madhya Pradesh 171

Madhya Pradesh 236

Maharashtra 29

Maharashtra 66

Maharashtra 52

Maharashtra 51

Maharashtra 30

Maharashtra 14

Maharashtra 18

Maharashtra 45

Maharashtra 40

Maharashtra 43

Maharashtra 37

Maharashtra 13

Maharashtra 22

Maharashtra 13

Maharashtra 38

Maharashtra 19

Maharashtra 97 


\begin{tabular}{|c|c|}
\hline 348 & Mumbai Suburban \\
\hline 349 & Nagpur \\
\hline 350 & Nanded \\
\hline 351 & Nandurbar \\
\hline 352 & Nashik \\
\hline 353 & Osmanabad \\
\hline 354 & Parbhani \\
\hline 355 & Pune \\
\hline 356 & Raigarh \\
\hline 357 & Ratnagiri \\
\hline 358 & Sangli \\
\hline 359 & Satara \\
\hline 360 & Sindhudurg \\
\hline 361 & Solapur \\
\hline 362 & Thane \\
\hline 363 & Wardha \\
\hline 364 & Washim \\
\hline 365 & Yavatmal \\
\hline 366 & Bishnupur \\
\hline 367 & Chandel \\
\hline 368 & Churachandpur \\
\hline 369 & Imphal East \\
\hline 370 & Imphal West \\
\hline 371 & Senapati \\
\hline 372 & Tamenglong \\
\hline 373 & Thoubal \\
\hline 374 & Ukhrul \\
\hline 375 & East Garo Hills \\
\hline 376 & East Khasi Hills \\
\hline 377 & Jaintia Hills \\
\hline 378 & Ribhoi \\
\hline 379 & South Garo Hills \\
\hline 380 & West Garo Hills \\
\hline 381 & West Khasi Hills \\
\hline 382 & Aizawl \\
\hline 383 & Champhai \\
\hline 384 & Kolasib \\
\hline 385 & Lawngtlai \\
\hline 386 & Lunglei \\
\hline 387 & Mamit \\
\hline 388 & Saiha \\
\hline 389 & Serchhip \\
\hline 390 & Dimapur \\
\hline 391 & Kiphire \\
\hline 392 & Kohima \\
\hline 393 & Longleng \\
\hline 394 & Mokokchung \\
\hline 395 & Mon \\
\hline 396 & Peren \\
\hline 397 & Phek \\
\hline
\end{tabular}

Maharashtra 0

Maharashtra 163

Maharashtra 23

Maharashtra 76

Maharashtra 52

Maharashtra 22

Maharashtra 8

Maharashtra 49

Maharashtra 36

Maharashtra 22

Maharashtra 50

Maharashtra 31

Maharashtra 62

Maharashtra 29

Maharashtra 26

Maharashtra 97

Maharashtra 7

Maharashtra 35

Manipur 255

Manipur $\quad 150$

Manipur $\quad 147$

Manipur $\quad 80$

Manipur $\quad 317$

Manipur $\quad 207$

Manipur $\quad 529$

Manipur 97

Manipur 332

Meghalaya $\quad 311$

Meghalaya 200

Meghalaya 212

Meghalaya 227

Meghalaya $\quad 590$

Meghalaya 317

Meghalaya 253

Mizoram 97

Mizoram 335

Mizoram 40

Mizoram 195

Mizoram 113

Mizoram 40

Mizoram 220

Mizoram 67

Nagaland 217

Nagaland 192

Nagaland 133

Nagaland 99

Nagaland 132

Nagaland 58

Nagaland $\quad 54$

Nagaland 194 


\begin{tabular}{|c|c|}
\hline 398 & Tuensang \\
\hline 399 & Wokha \\
\hline 400 & Zunheboto \\
\hline 401 & Anugul \\
\hline 402 & Balangir \\
\hline 403 & Baleshwar \\
\hline 404 & Bargarh \\
\hline 405 & Baudh \\
\hline 406 & Bhadrak \\
\hline 407 & Cuttack \\
\hline 408 & Debagarh \\
\hline 409 & Dhenkanal \\
\hline 410 & Gajapati \\
\hline 411 & Ganjam \\
\hline 412 & Jagatsinghapur \\
\hline 413 & Jajapur \\
\hline 414 & Jharsuguda \\
\hline 415 & Kalahandi \\
\hline 416 & Kandhamal \\
\hline 417 & Kendrapara \\
\hline 418 & Kendujhar \\
\hline 419 & Khordha \\
\hline 420 & Koraput \\
\hline 421 & Malkangiri \\
\hline 422 & Mayurbhanj \\
\hline 423 & Nabarangapur \\
\hline 424 & Nayagarh \\
\hline 425 & Nuapada \\
\hline 426 & Puri \\
\hline 427 & Rayagada \\
\hline 428 & Sambalpur \\
\hline 429 & Subarnapur \\
\hline 430 & Sundargarh \\
\hline 431 & Karaikal \\
\hline 432 & Mahe \\
\hline 433 & Pudducherry \\
\hline 434 & Yanam \\
\hline 435 & Amritsar \\
\hline 436 & Barnala \\
\hline 437 & Bathinda \\
\hline 438 & Faridkot \\
\hline 439 & Fatehgarh Sahib \\
\hline 440 & Firozpur \\
\hline 441 & Gurdaspur \\
\hline 442 & Hoshiarpur \\
\hline 443 & Jalandhar \\
\hline 444 & Kapurthala \\
\hline 445 & Ludhiana \\
\hline 446 & Mansa \\
\hline 447 & Moga \\
\hline
\end{tabular}

Nagaland 88

Nagaland 156

Nagaland $\quad 152$

Odisha 197

Odisha 122

Odisha 108

Odisha 77

Odisha 81

Odisha 48

Odisha 122

Odisha 158

Odisha 78

Odisha 168

Odisha 186

Odisha 83

Odisha 98

Odisha 65

Odisha 203

Odisha 287

Odisha 97

Odisha 69

Odisha 45

Odisha 260

Odisha 286

Odisha 139

Odisha 223

Odisha 122

Odisha 301

Odisha 88

Odisha $\quad 180$

Odisha 327

Odisha 255

Odisha 111

Puducherry 32

Puducherry 49

Puducherry 45

Puducherry 0

Punjab 310

Punjab 89

Punjab 104

Punjab 429

Punjab 159

Punjab 195

Punjab 70

Punjab 44

Punjab 63

Punjab 71

Punjab 85

Punjab 80

Punjab 44 


\begin{tabular}{|c|c|c|c|}
\hline 448 & Muktsar & Punjab & 133 \\
\hline 449 & Patiala & Punjab & 212 \\
\hline 450 & Rupnagar & Punjab & 109 \\
\hline 451 & Sahibzada Ajit Singh Nagar & Punjab & 155 \\
\hline 452 & Sangrur & Punjab & 64 \\
\hline 453 & Shahid Bhagat Singh Nagar & Punjab & 105 \\
\hline 454 & Tarn Taran & Punjab & 35 \\
\hline 455 & Ajmer & Rajasthan & 179 \\
\hline 456 & Alwar & Rajasthan & 158 \\
\hline 457 & Banswara & Rajasthan & 243 \\
\hline 458 & Baran & Rajasthan & 174 \\
\hline 459 & Barmer & Rajasthan & 123 \\
\hline 460 & Bharatpur & Rajasthan & 160 \\
\hline 461 & Bhilwara & Rajasthan & 96 \\
\hline 462 & Bikaner & Rajasthan & 128 \\
\hline 463 & Bundi & Rajasthan & 133 \\
\hline 464 & Chittaurgarh & Rajasthan & 123 \\
\hline 465 & Churu & Rajasthan & 198 \\
\hline 466 & Dausa & Rajasthan & 110 \\
\hline 467 & Dhaulpur & Rajasthan & 208 \\
\hline 468 & Dungarpur & Rajasthan & 220 \\
\hline 469 & Ganganagar & Rajasthan & 104 \\
\hline 470 & Hanumangarh & Rajasthan & 110 \\
\hline 471 & Jaipur & Rajasthan & 102 \\
\hline 472 & Jaisalmer & Rajasthan & 67 \\
\hline 473 & Jalor & Rajasthan & 131 \\
\hline 474 & Jhalawar & Rajasthan & 209 \\
\hline 475 & Jhunjhunun & Rajasthan & 166 \\
\hline 476 & Jodhpur & Rajasthan & 170 \\
\hline 477 & Karauli & Rajasthan & 158 \\
\hline 478 & Kota & Rajasthan & 275 \\
\hline 479 & Nagaur & Rajasthan & 120 \\
\hline 480 & Pali & Rajasthan & 208 \\
\hline 481 & Pratapgarh & Rajasthan & 244 \\
\hline 482 & Rajsamand & Rajasthan & 327 \\
\hline 483 & Sawai Madhopur & Rajasthan & 136 \\
\hline 484 & Sikar & Rajasthan & 117 \\
\hline 485 & Sirohi & Rajasthan & 273 \\
\hline 486 & Tonk & Rajasthan & 140 \\
\hline 487 & Udaipur & Rajasthan & 298 \\
\hline 488 & East District & Sikkim & 202 \\
\hline 489 & North District & Sikkim & 376 \\
\hline 490 & South District & Sikkim & 309 \\
\hline 491 & West District & Sikkim & 152 \\
\hline 492 & Ariyalur & Tamil Nadu & 28 \\
\hline 493 & Chennai & Tamil Nadu & 76 \\
\hline 494 & Coimbatore & Tamil Nadu & 117 \\
\hline 495 & Cuddalore & Tamil Nadu & 39 \\
\hline 496 & Dharmapuri & Tamil Nadu & 44 \\
\hline 497 & Dindigul & Tamil Nadu & 21 \\
\hline
\end{tabular}




\begin{tabular}{|c|c|}
\hline 498 & Erode \\
\hline 499 & Kancheepuram \\
\hline 500 & Kanniyakumari \\
\hline 501 & Karur \\
\hline 502 & Krishnagiri \\
\hline 503 & Madurai \\
\hline 504 & Nagapattinam \\
\hline 505 & Namakkal \\
\hline 506 & Perambalur \\
\hline 507 & Pudukkottai \\
\hline 508 & Ramanathapuram \\
\hline 509 & Salem \\
\hline 510 & Sivaganga \\
\hline 511 & Thanjavur \\
\hline 512 & The Nilgiris \\
\hline 513 & Theni \\
\hline 514 & Thiruvallur \\
\hline 515 & Thiruvarur \\
\hline 516 & Thoothukkudi \\
\hline 517 & Tiruchirappalli \\
\hline 518 & Tirunelveli \\
\hline 519 & Tiruppur \\
\hline 520 & Tiruvannamalai \\
\hline 521 & Vellore \\
\hline 522 & Viluppuram \\
\hline 523 & Virudhunagar \\
\hline 524 & Adilabad \\
\hline 525 & Hyderabad \\
\hline 526 & Karimnagar \\
\hline 527 & Khammam \\
\hline 528 & Mahbubnagar \\
\hline 529 & Medak \\
\hline 530 & Nalgonda \\
\hline 531 & Nizamabad \\
\hline 532 & Rangareddy \\
\hline 533 & Warangal \\
\hline 534 & Dhalai \\
\hline 535 & North Tripura \\
\hline 536 & South Tripura \\
\hline 537 & West Tripura \\
\hline 538 & Agra \\
\hline 539 & Aligarh \\
\hline 540 & Allahabad \\
\hline 541 & Ambedkar Nagar \\
\hline 542 & Auraiya \\
\hline 543 & Azamgarh \\
\hline 544 & Baghpat \\
\hline 545 & Bahraich \\
\hline 546 & Ballia \\
\hline 547 & Balrampur \\
\hline
\end{tabular}

Tamil Nadu 43

Tamil Nadu $\quad 40$

Tamil Nadu 28

Tamil Nadu 9

Tamil Nadu 25

Tamil Nadu 123

Tamil Nadu 25

Tamil Nadu 22

Tamil Nadu $\quad 59$

Tamil Nadu 43

Tamil Nadu 31

Tamil Nadu $\quad 91$

Tamil Nadu 19

Tamil Nadu $\quad 86$

Tamil Nadu $\quad 50$

Tamil Nadu 49

Tamil Nadu 39

Tamil Nadu 80

Tamil Nadu $\quad 53$

Tamil Nadu 92

Tamil Nadu $\quad 72$

Tamil Nadu 28

Tamil Nadu $\quad 55$

Tamil Nadu $\quad 37$

Tamil Nadu $\quad 82$

Tamil Nadu 38

Telangana 60

Telangana 124

Telangana 36

Telangana 95

Telangana $\quad 52$

Telangana $\quad 46$

Telangana 43

Telangana 37

Telangana 9

Telangana 49

Tripura 104

Tripura 217

Tripura 100

Tripura 93

Uttar Pradesh 182

Uttar Pradesh 128

Uttar Pradesh 276

Uttar Pradesh 344

Uttar Pradesh 397

Uttar Pradesh 122

Uttar Pradesh 140

Uttar Pradesh $\quad 140$

Uttar Pradesh 26

Uttar Pradesh 153 


\begin{tabular}{|c|c|}
\hline 548 & Banda \\
\hline 549 & Bara Banki \\
\hline 550 & Bareilly \\
\hline 551 & Basti \\
\hline 552 & Bijnor \\
\hline 553 & Budaun \\
\hline 554 & Bulandshahr \\
\hline 555 & Chandauli \\
\hline 556 & Chitrakoot \\
\hline 557 & Deoria \\
\hline 558 & Etah \\
\hline 559 & Etawah \\
\hline 560 & Faizabad \\
\hline 561 & Farrukhabad \\
\hline 562 & Fatehpur \\
\hline 563 & Firozabad \\
\hline 564 & Gautam Buddha Nagar \\
\hline 565 & Ghaziabad \\
\hline 566 & Ghazipur \\
\hline 567 & Gonda \\
\hline 568 & Gorakhpur \\
\hline 569 & Hamirpur \\
\hline 570 & Hardoi \\
\hline 571 & Jalaun \\
\hline 572 & Jaunpur \\
\hline 573 & Jhansi \\
\hline 574 & Jyotiba Phule Nagar \\
\hline 575 & Kannauj \\
\hline 576 & Kanpur Dehat \\
\hline 577 & Kanpur Nagar \\
\hline 578 & Kanshiram Nagar \\
\hline 579 & Kaushambi \\
\hline 580 & Kheri \\
\hline 581 & Kushinagar \\
\hline 582 & Lalitpur \\
\hline 583 & Lucknow \\
\hline 584 & Mahamaya Nagar \\
\hline 585 & Mahoba \\
\hline 586 & Mahrajganj \\
\hline 587 & Mainpuri \\
\hline 588 & Mathura \\
\hline 589 & Mau \\
\hline 590 & Meerut \\
\hline 591 & Mirzapur \\
\hline 592 & Moradabad \\
\hline 593 & Muzaffarnagar \\
\hline 594 & Pilibhit \\
\hline 595 & Pratapgarh \\
\hline 596 & Rae Bareli \\
\hline 597 & Rampur \\
\hline
\end{tabular}

Uttar Pradesh 179

Uttar Pradesh 202

Uttar Pradesh 62

Uttar Pradesh 226

Uttar Pradesh 161

Uttar Pradesh 264

Uttar Pradesh 149

Uttar Pradesh 158

Uttar Pradesh 147

Uttar Pradesh 344

Uttar Pradesh 487

Uttar Pradesh 329

Uttar Pradesh 395

Uttar Pradesh 173

Uttar Pradesh $\quad 106$

Uttar Pradesh 84

Uttar Pradesh 73

Uttar Pradesh 67

Uttar Pradesh 240

Uttar Pradesh 41

Uttar Pradesh 272

Uttar Pradesh 119

Uttar Pradesh 154

Uttar Pradesh 265

Uttar Pradesh 170

Uttar Pradesh 156

Uttar Pradesh 375

Uttar Pradesh 185

Uttar Pradesh 84

Uttar Pradesh 101

Uttar Pradesh 141

Uttar Pradesh 254

Uttar Pradesh 126

Uttar Pradesh 83

Uttar Pradesh 261

Uttar Pradesh 971

Uttar Pradesh 18

Uttar Pradesh 147

Uttar Pradesh 219

Uttar Pradesh 44

Uttar Pradesh 191

Uttar Pradesh 329

Uttar Pradesh 154

Uttar Pradesh 90

Uttar Pradesh 152

Uttar Pradesh 126

Uttar Pradesh 304

Uttar Pradesh 114

Uttar Pradesh 107

Uttar Pradesh 248 


\begin{tabular}{|c|c|c|c|}
\hline 598 & Saharanpur & Uttar Pradesh & 160 \\
\hline 599 & Sant Kabir Nagar & Uttar Pradesh & 236 \\
\hline 600 & Sant Ravidas Nagar (Bhadohi) & Uttar Pradesh & 224 \\
\hline 601 & Shahjahanpur & Uttar Pradesh & 118 \\
\hline 602 & Shrawasti & Uttar Pradesh & 302 \\
\hline 603 & Siddharthnagar & Uttar Pradesh & 194 \\
\hline 604 & Sitapur & Uttar Pradesh & 278 \\
\hline 605 & Sonbhadra & Uttar Pradesh & 312 \\
\hline 606 & Sultanpur & Uttar Pradesh & 443 \\
\hline 607 & Unnao & Uttar Pradesh & 334 \\
\hline 608 & Varanasi & Uttar Pradesh & 218 \\
\hline 609 & Almora & Uttarakhand & 57 \\
\hline 610 & Bageshwar & Uttarakhand & 0 \\
\hline 611 & Chamoli & Uttarakhand & 113 \\
\hline 612 & Champawat & Uttarakhand & 202 \\
\hline 613 & Dehradun & Uttarakhand & 180 \\
\hline 614 & Garhwal & Uttarakhand & 45 \\
\hline 615 & Hardwar & Uttarakhand & 131 \\
\hline 616 & Nainital & Uttarakhand & 82 \\
\hline 617 & Pithoragarh & Uttarakhand & 94 \\
\hline 618 & Rudraprayag & Uttarakhand & 65 \\
\hline 619 & Tehri Garhwal & Uttarakhand & 110 \\
\hline 620 & Udham Singh Nagar & Uttarakhand & 88 \\
\hline 621 & Uttarkashi & Uttarakhand & 61 \\
\hline 622 & Bankura & West Bengal & 112 \\
\hline 623 & Barddhaman & West Bengal & 104 \\
\hline 624 & Birbhum & West Bengal & 103 \\
\hline 625 & Dakshin Dinajpur & West Bengal & 104 \\
\hline 626 & Darjiling & West Bengal & 253 \\
\hline 627 & Haora & West Bengal & 121 \\
\hline 628 & Hugli & West Bengal & 61 \\
\hline 629 & Jalpaiguri & West Bengal & 125 \\
\hline 630 & Koch Bihar & West Bengal & 114 \\
\hline 631 & Kolkata & West Bengal & 146 \\
\hline 632 & Maldah & West Bengal & 97 \\
\hline 633 & Murshidabad & West Bengal & 137 \\
\hline 634 & Nadia & West Bengal & 104 \\
\hline 635 & North Twenty Four Parganas & West Bengal & 43 \\
\hline 636 & Paschim Medinipur & West Bengal & 70 \\
\hline 637 & Purba Medinipur & West Bengal & 38 \\
\hline 638 & Puruliya & West Bengal & 82 \\
\hline 639 & South Twenty Four Parganas & West Bengal & 68 \\
\hline 640 & Uttar Dinajpur & West Bengal & 77 \\
\hline
\end{tabular}


Supplementary Figure 1. Bivariate LISA (Cluster and Significance) maps depicting spatial clustering and spatial outliers of maternal mortality ratio by selected background characteristics in India
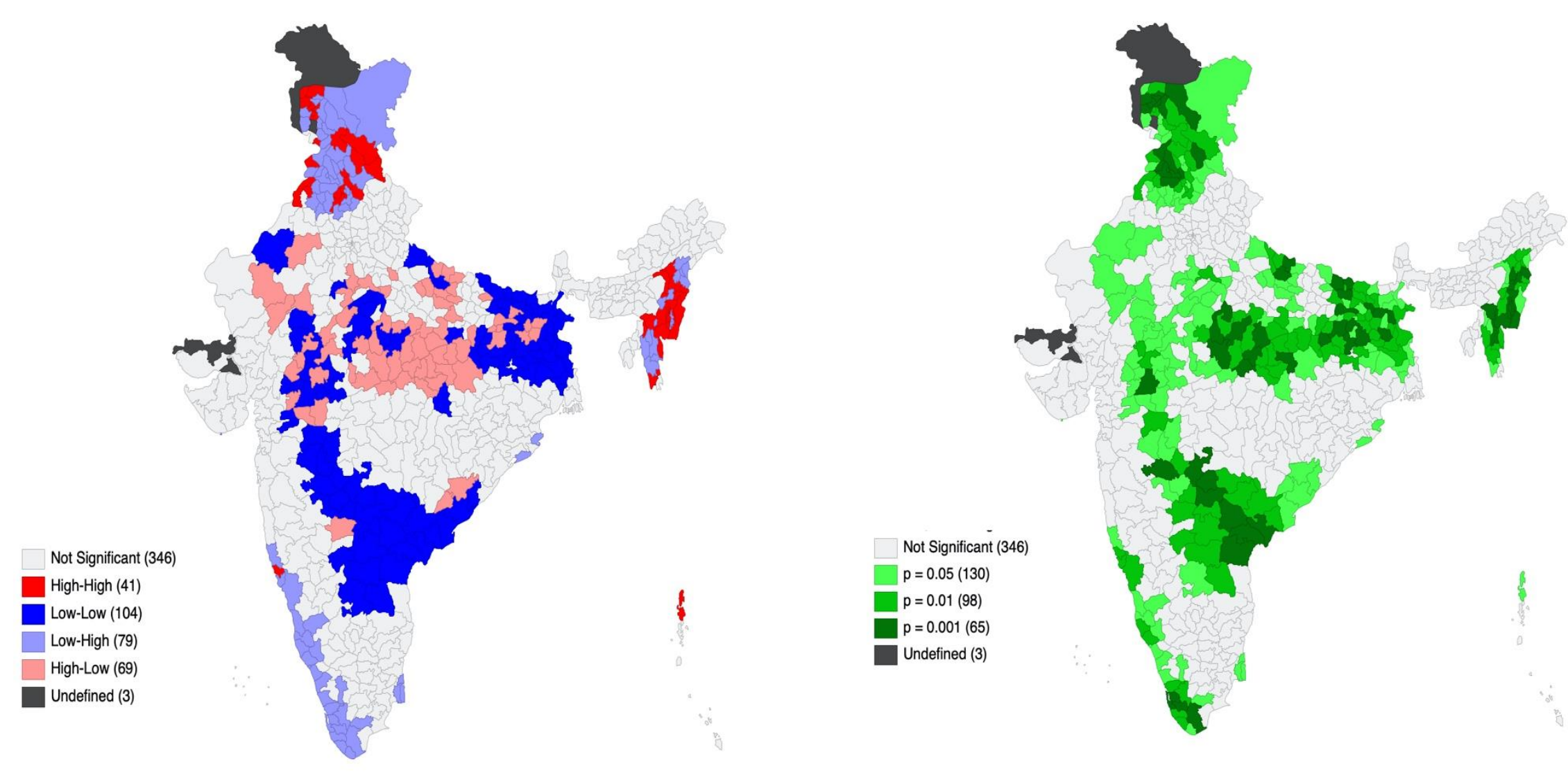

Bivariate LISA (Cluster and Significance) maps depicting spatial clustering and spatial outliers of maternal mortality ratio by mean age at marriage in India (Moran's $\mathrm{I}=0.000$, $\mathrm{p}$-value $=0.498$ ) 

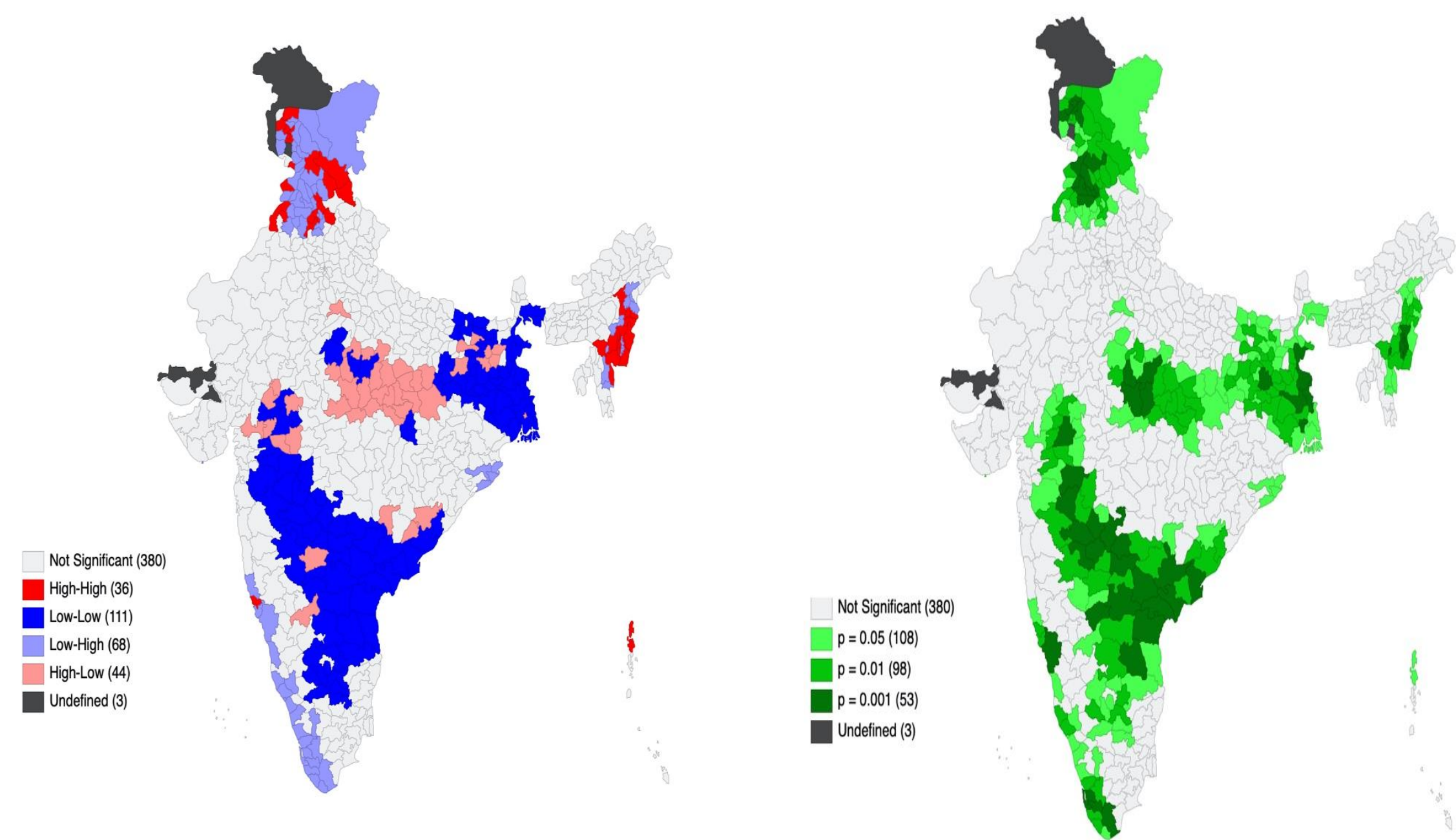

Bivariate LISA (Cluster and Significance) maps depicting spatial clustering and spatial outliers of maternal mortality ratio by mean age at first birth in India (Moran's I=0.035, p-value $=0.0350$ ) 

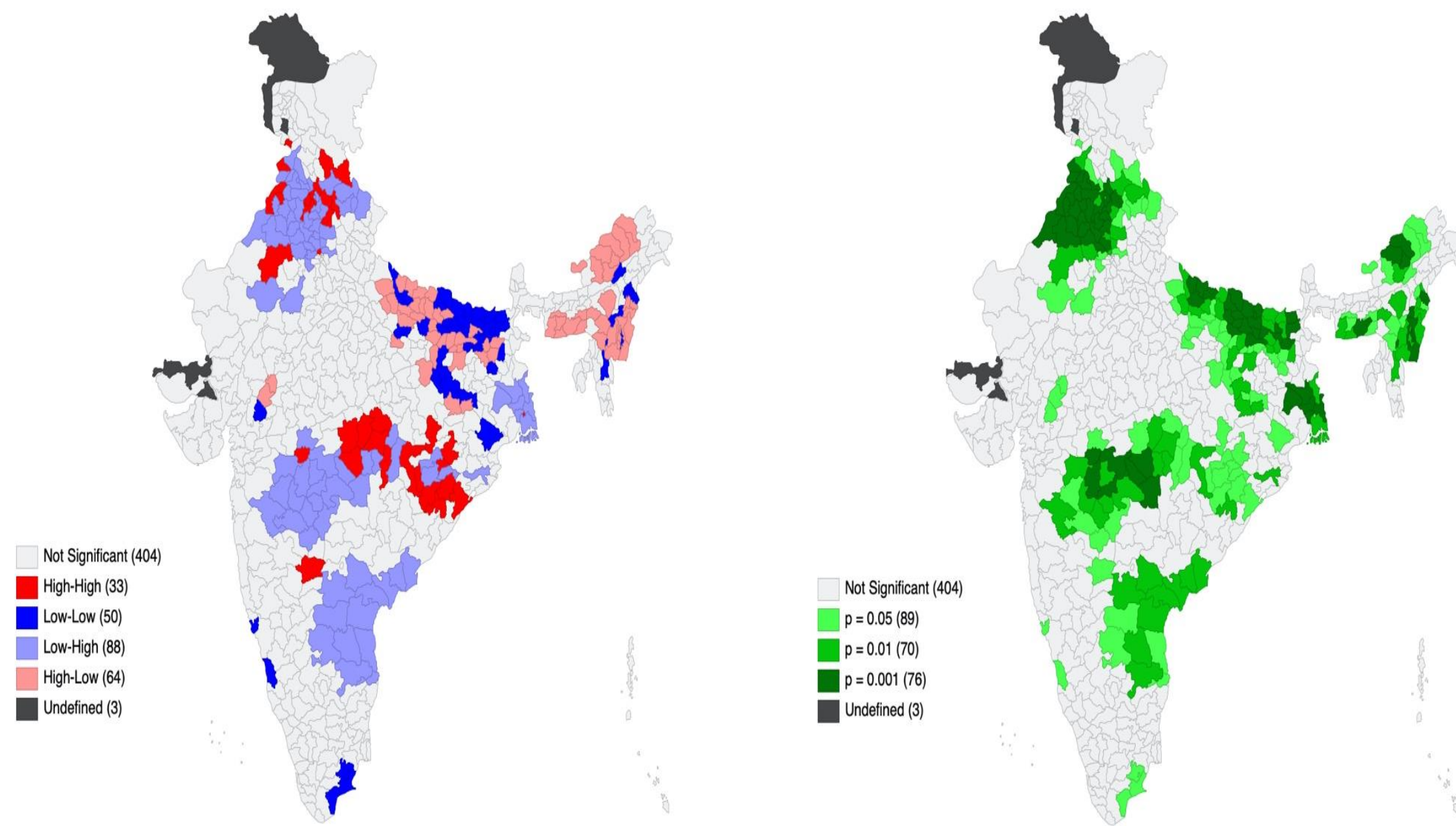

Bivariate LISA (Cluster and Significance) maps depicting spatial clustering and spatial outliers of maternal mortality ratio by contraception use in India (Moran's I=-0.166, p-value=0.001) 

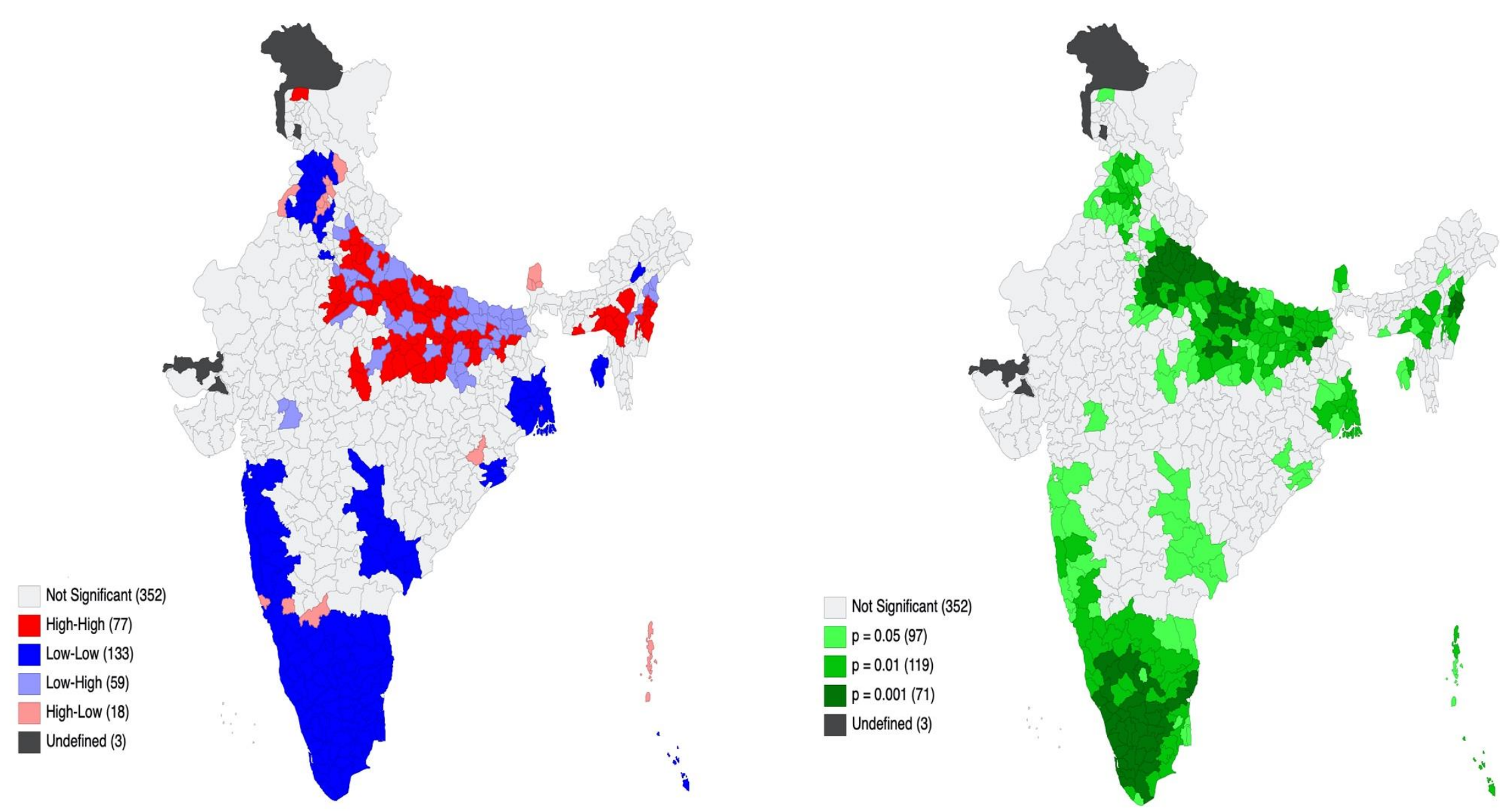

Bivariate LISA (Cluster and Significance) maps depicting spatial clustering and spatial outliers of maternal mortality ratio by mean number of children ever born in India (Moran's I $=0.258$, $p$-value $=0.001$ ) 

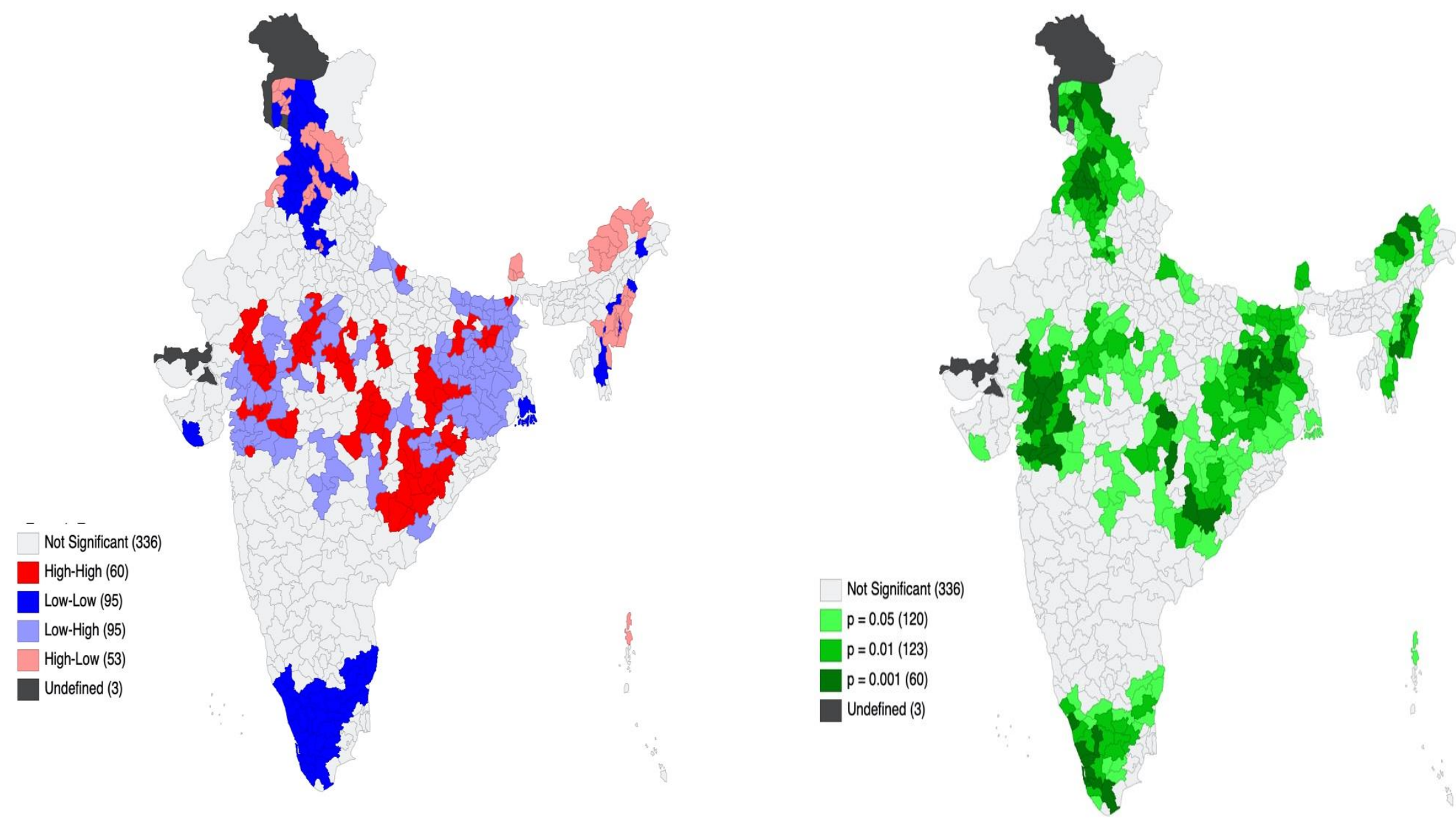

Bivariate LISA (Cluster and Significance) maps depicting spatial clustering and spatial outliers of maternal mortality ratio by percent of women underweight in India (Moran's I=0.024, p-value $=0.091$ ) 

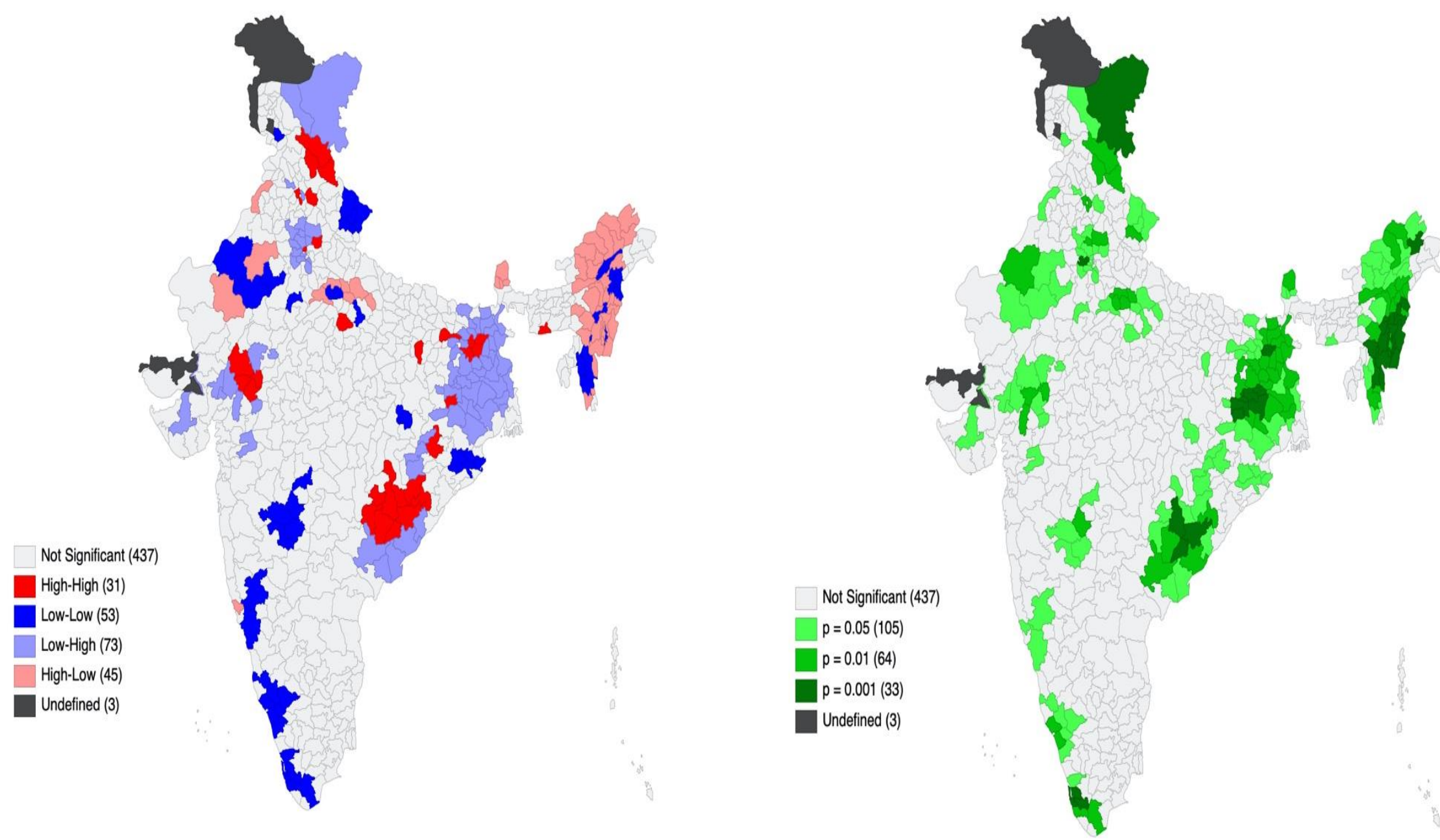

Bivariate LISA (Cluster and Significance) maps depicting spatial clustering and spatial outliers of maternal mortality ratio by percent of anaemic women mean in India (Moran's I=-0.045, p-value=0.019) 

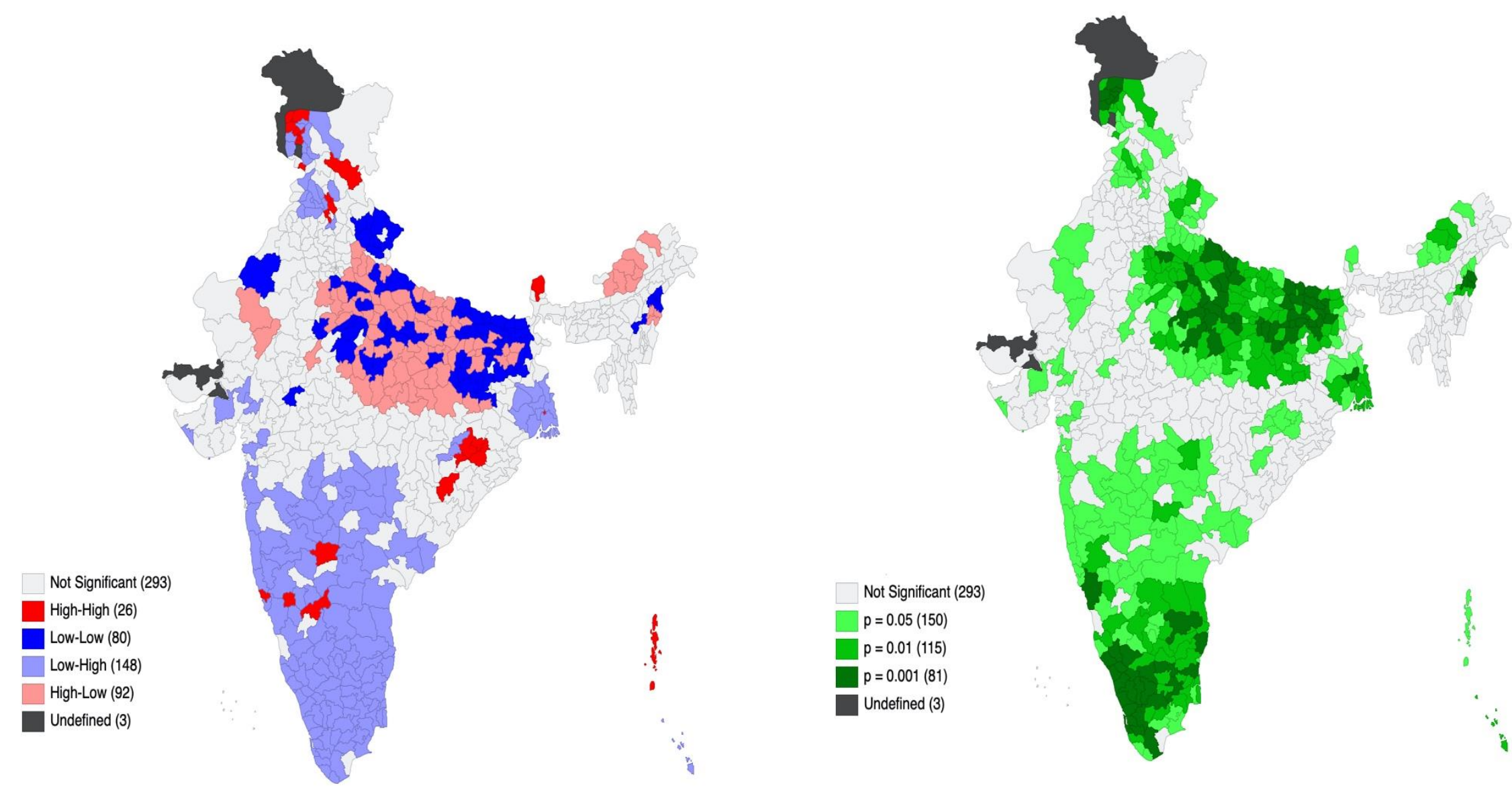

Bivariate LISA (Cluster and Significance) maps depicting spatial clustering and spatial outliers of maternal mortality ratio by percent of women receiving four or more Antenatal care in India (Moran's I=-0.241, p-value $=0.001$ ) 

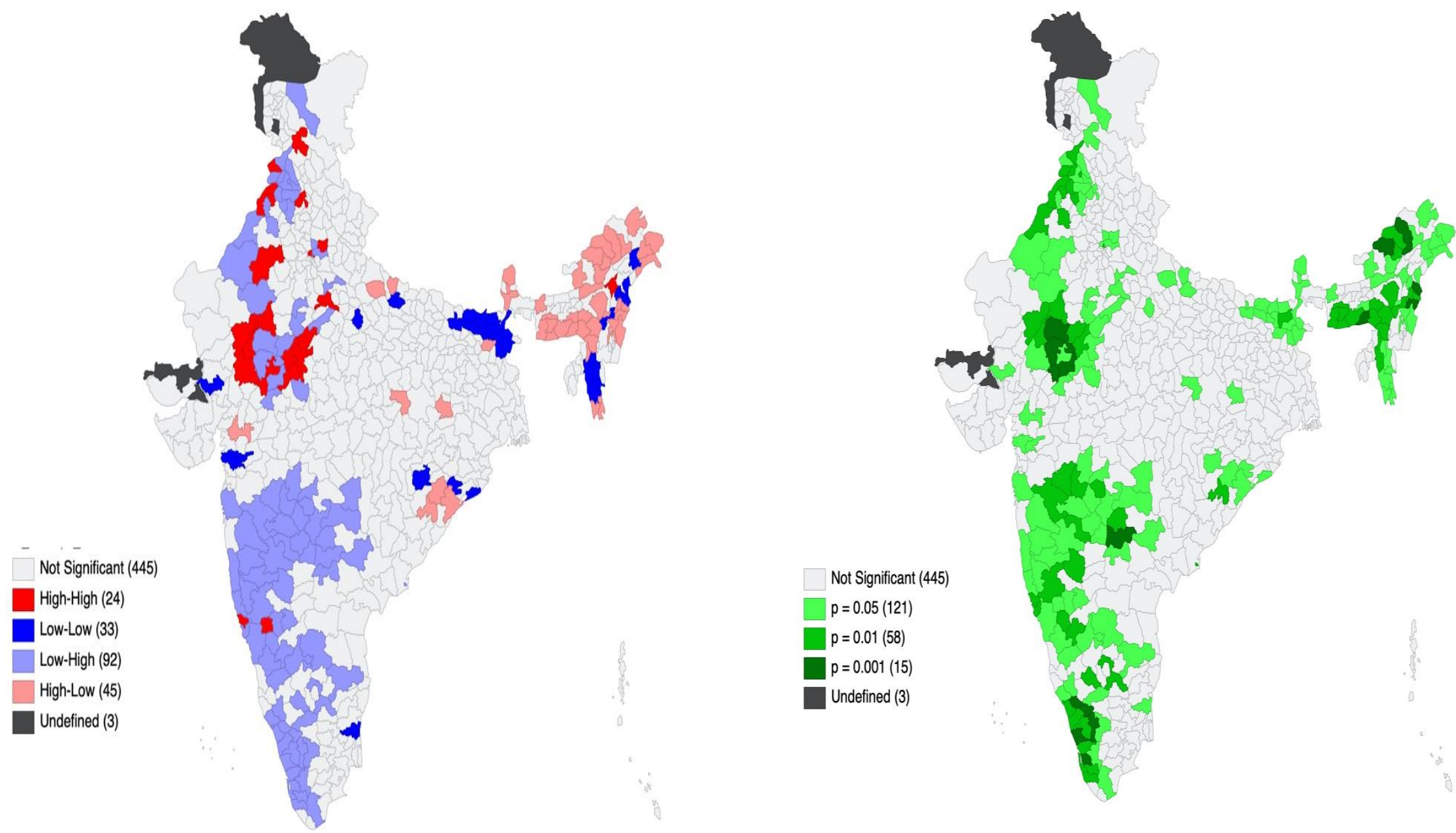

Bivariate LISA (Cluster and Significance) maps depicting spatial clustering and spatial outliers of maternal mortality ratio by percent women receiving Postnatal care in India (Moran's I=-0.168, p-value=0.001) 

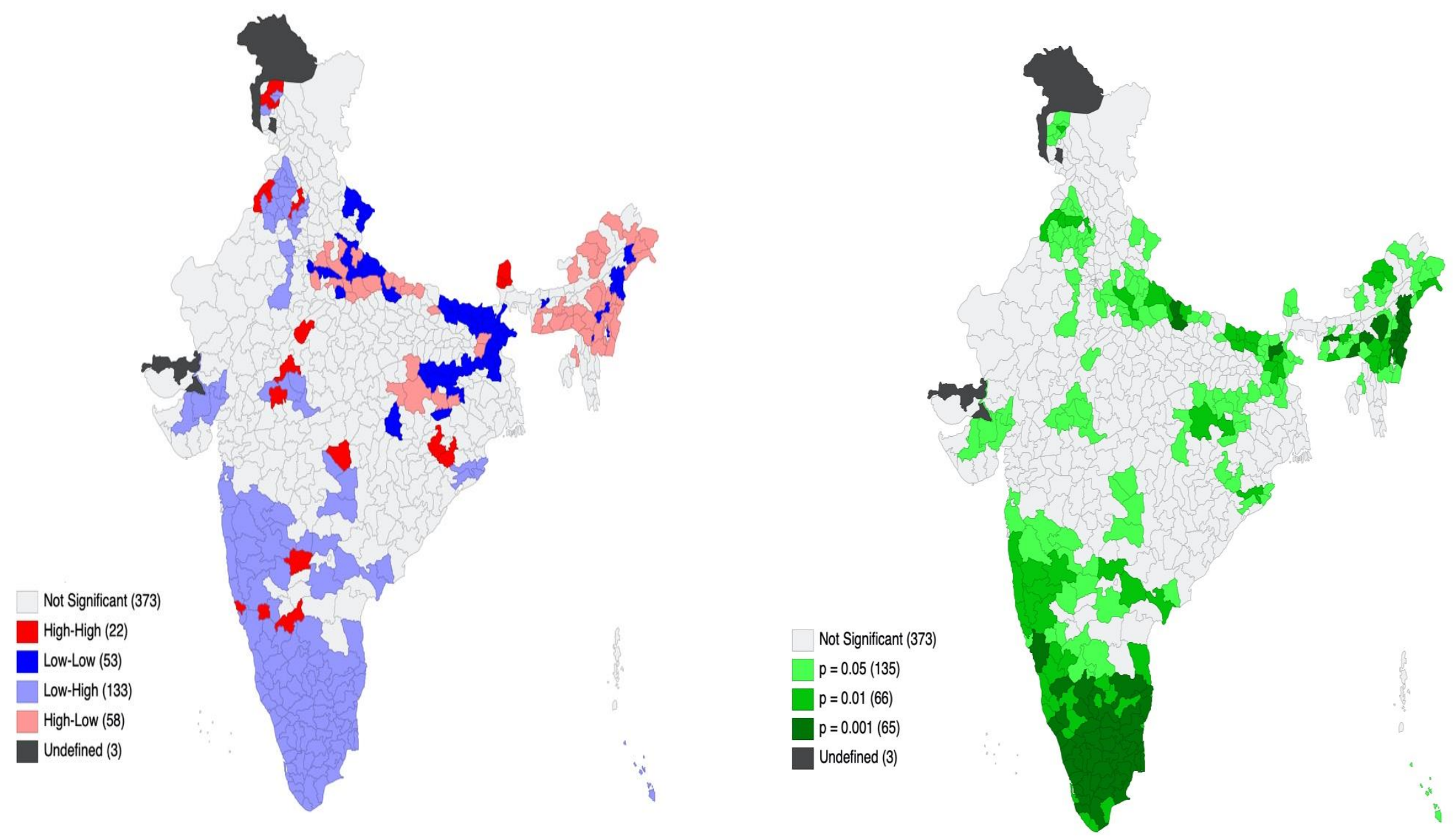

Bivariate LISA (Cluster and Significance) maps depicting spatial clustering and spatial outliers of maternal mortality ratio by percent of institutional delivery in India (Moran's I=-0.233, p-value $=0.001$ ) 

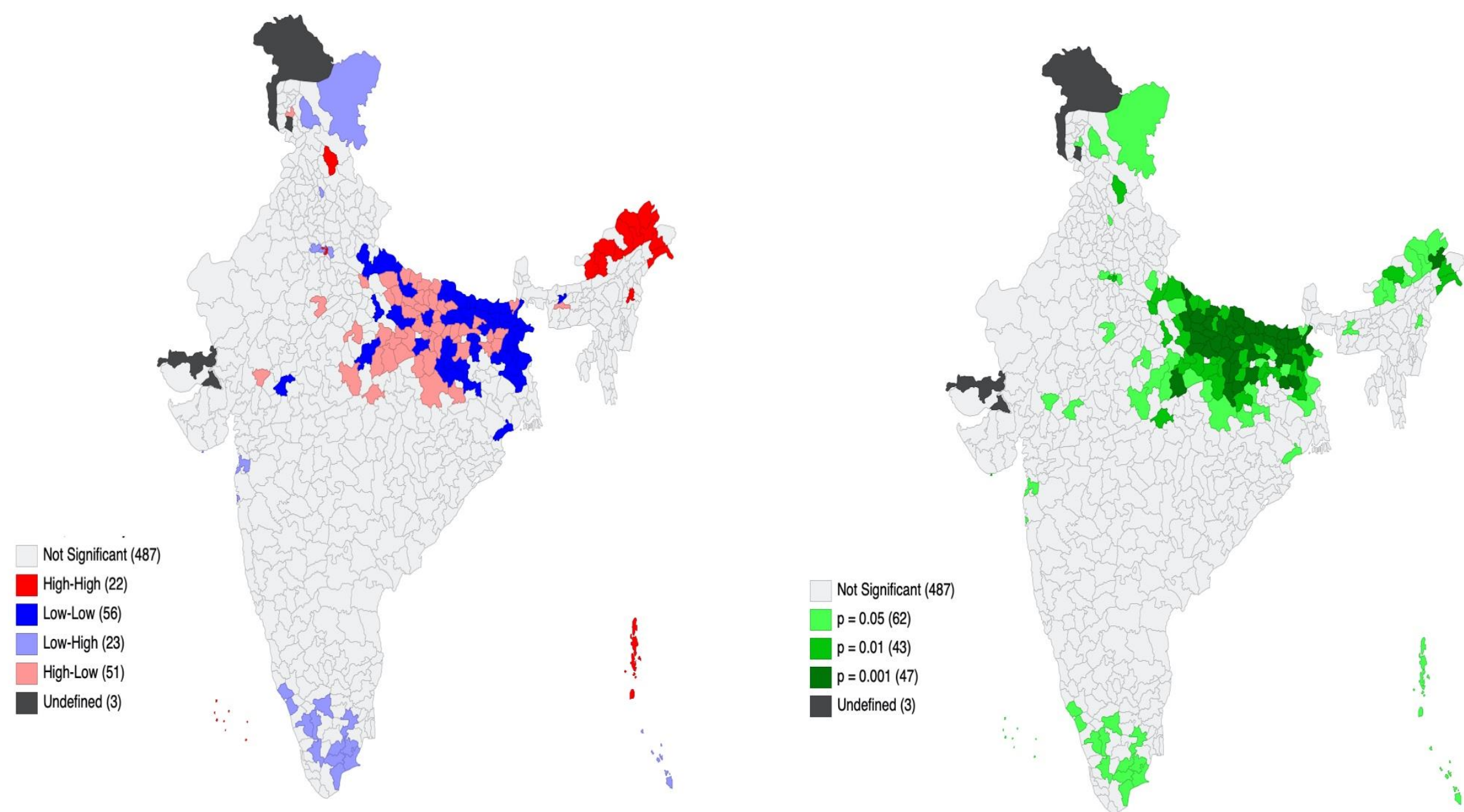

Bivariate LISA (Cluster and Significance) maps depicting spatial clustering and spatial outliers of maternal mortality ratio by healthcare index in India (Moran's I=-0.042, $\mathrm{p}$-value $=0.001$ ) 


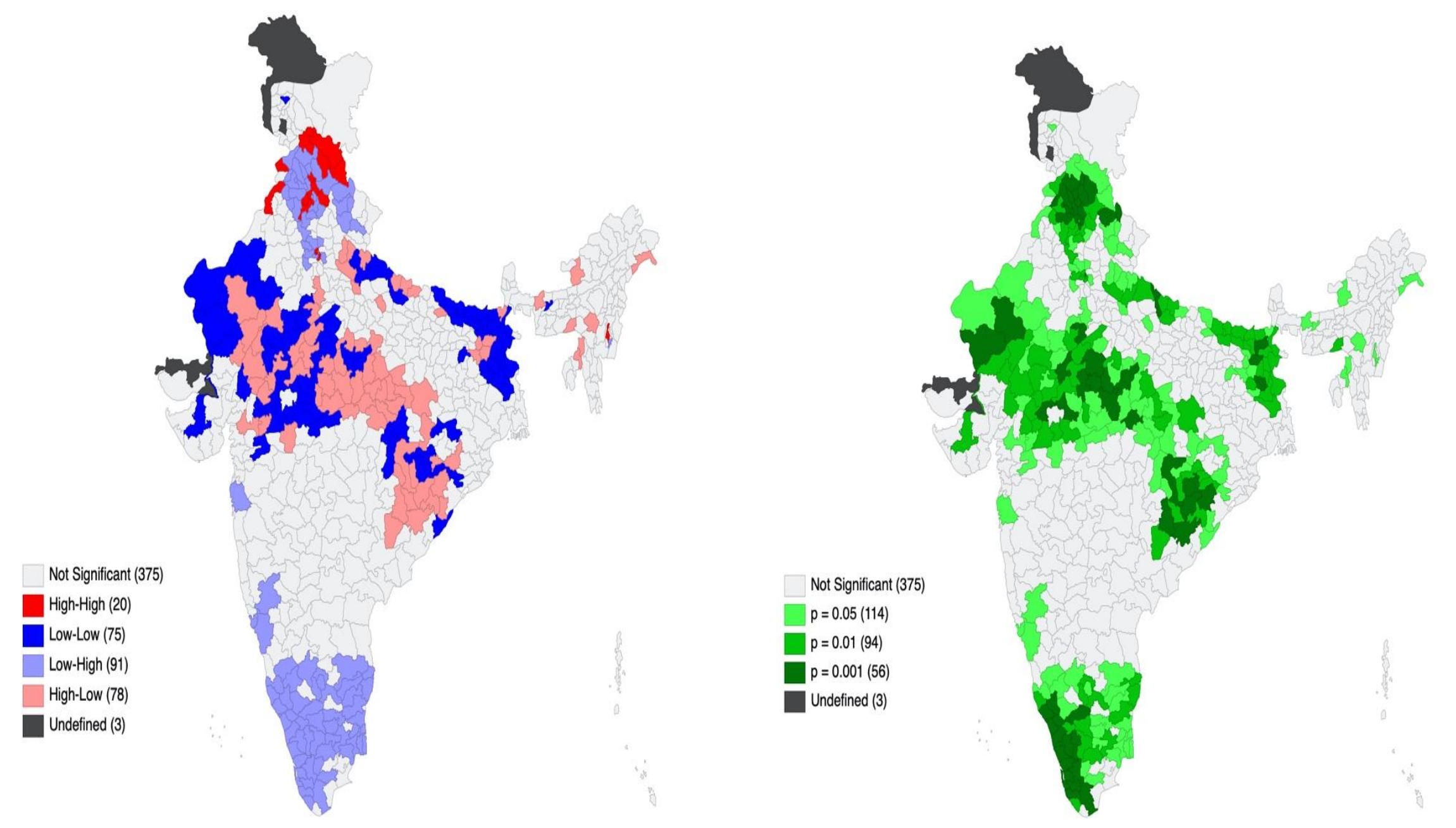

Bivariate LISA (Cluster and Significance) maps depicting spatial clustering and spatial outliers of maternal mortality ratio by percent women with ten or more years of schooling in India (Moran's I=-0.017, $\mathrm{p}$-value $=0.001$ ) 

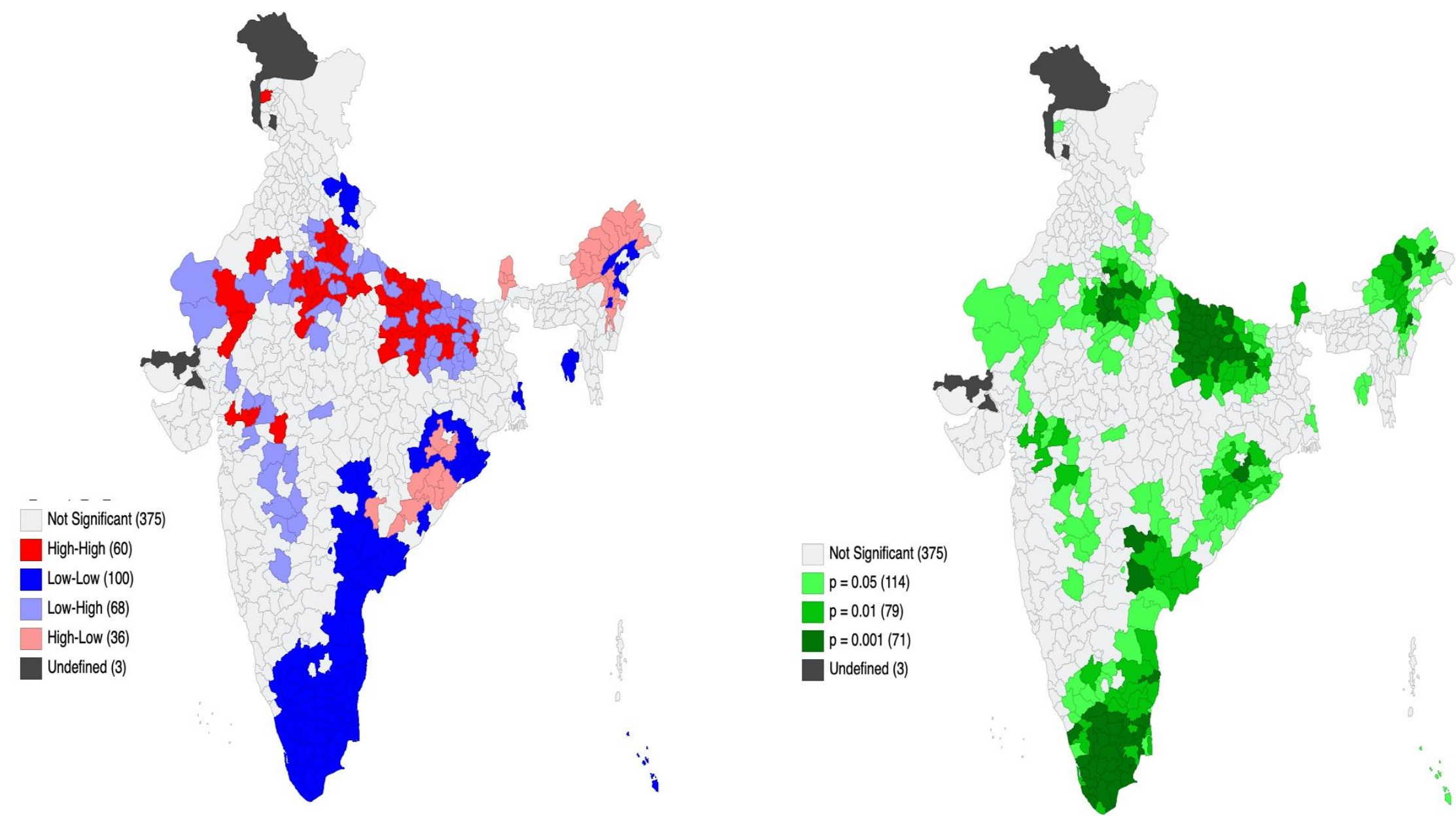

Bivariate LISA (Cluster and Significance) maps depicting spatial clustering and spatial outliers of maternal mortality ratio by average household size in India (Moran's I=0.110, p-value=0.001) 

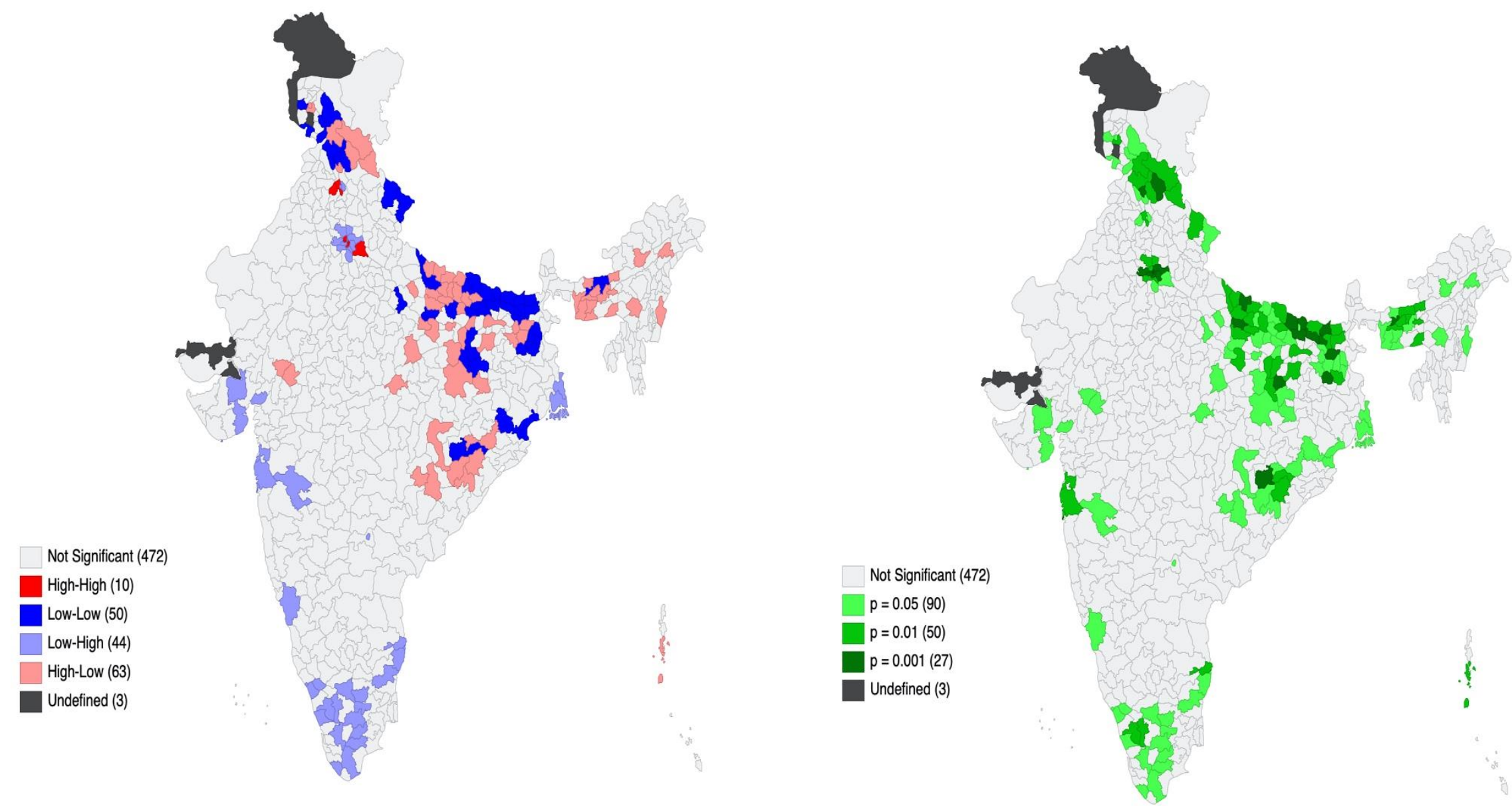

Bivariate LISA (Cluster and Significance) maps depicting spatial clustering and spatial outliers of maternal mortality ratio by percent women residing in urban areas in India (Moran's I=-0.152, p-value=0.001) 

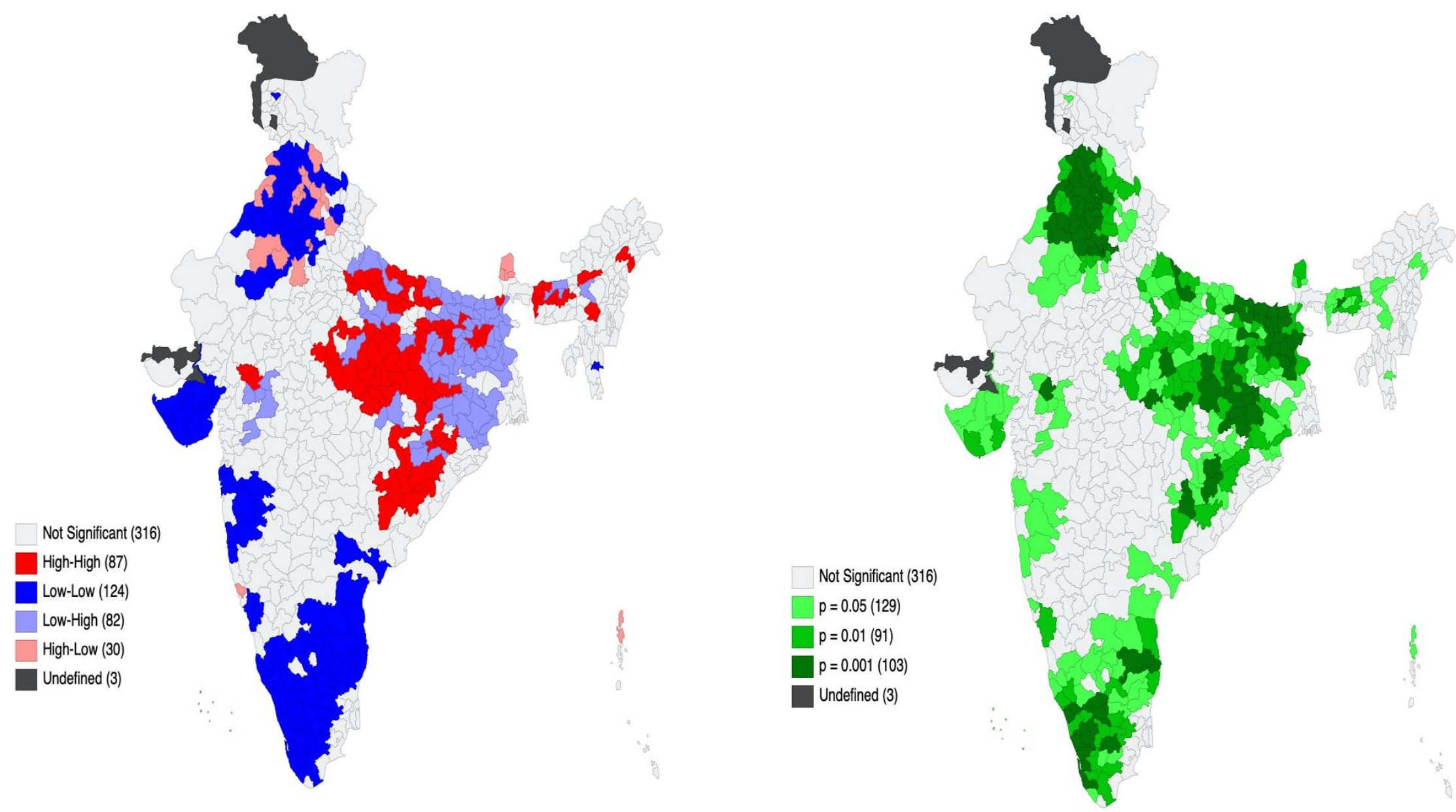

Bivariate LISA (Cluster and Significance) maps depicting spatial clustering and spatial outliers of maternal mortality ratio by percent poor in India (Moran's I $=0.215$, $\mathrm{p}$-value $=0.001$ ) 

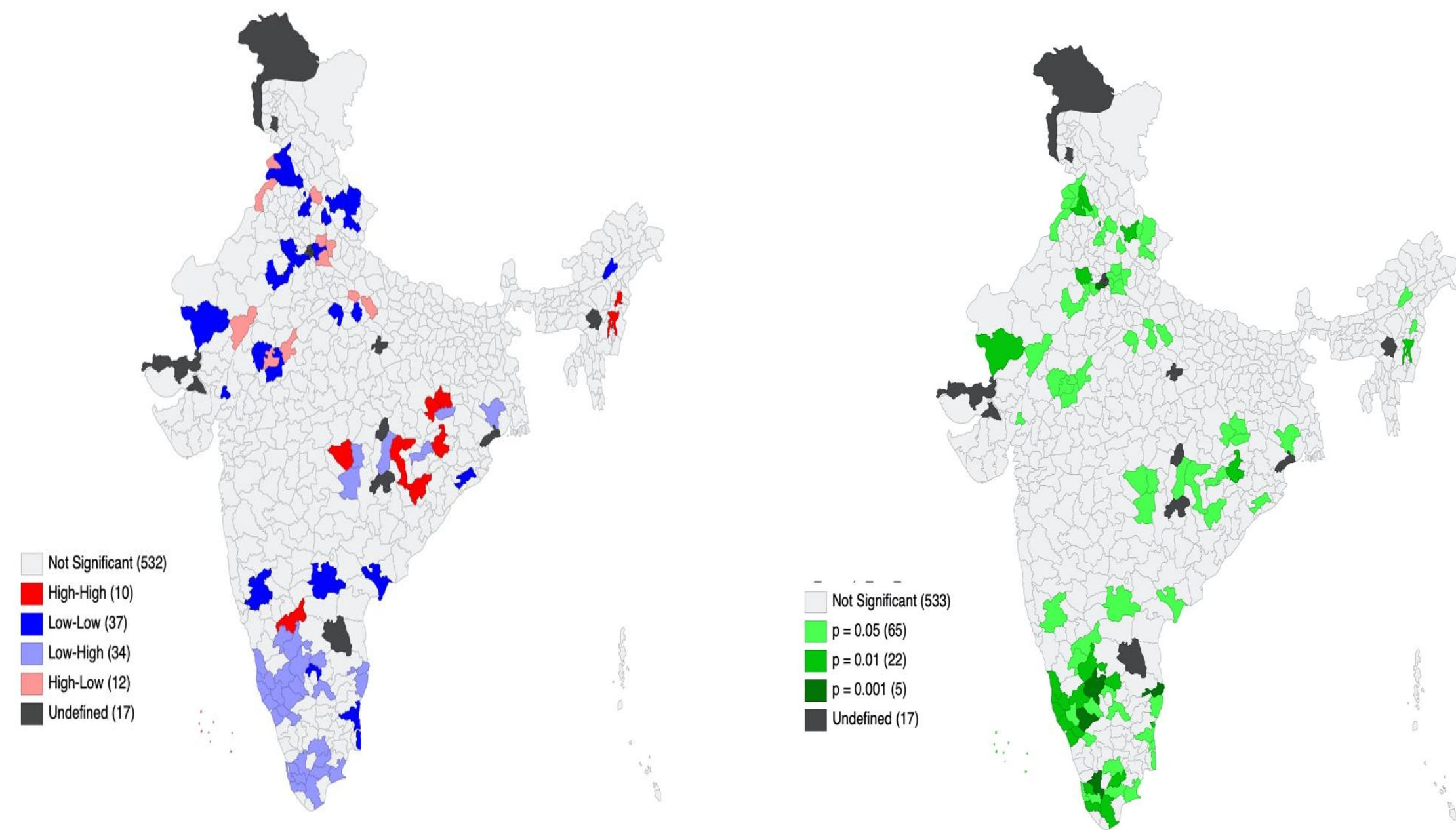

Bivariate LISA (Cluster and Significance) maps depicting spatial clustering and spatial outliers of maternal mortality ratio by sex ratio at birth in India (Moran's I=-0.017, $\mathrm{p}$-value $=0.189$ ) 
medRxiv preprint doi: https://doi.org/10.1101/2021.09.28.21264229; this version posted October 15, 2021. The copyright holder for this preprint (which was not certified by peer review) is the author/funder, who has granted medRxiv a license to display the preprint in All rights reserved. No reuse allowed without permission.

Supplementary Table 4. Comparison of Infant Mortality Rate, Sex Ratio at Birth and Crude Birth Rate from SRS and HMIS

\begin{tabular}{|l|l|l|}
\hline Indicator & SRS (2018) & HMIS (2017-19) \\
\hline Infant Mortality Rate & 32 & 26.2 \\
\hline Sex Ratio at Birth & 111 & 108 \\
\hline Crude Birth Rate & 20.2 & 24 \\
\hline
\end{tabular}

